\title{
Why individual investors want dividends
}

\author{
Ming Dong ${ }^{\mathrm{a}}$, Chris Robinson ${ }^{\mathrm{b}}$, Chris Veld ${ }^{\mathrm{c}, *}$ \\ ${ }^{a}$ Schulich School of Business, York University, Toronto, ON, M3J 1P3, Canada \\ ${ }^{\mathrm{b}}$ Atkinson School of Administrative Studies, York University, Toronto, ON, M3J 1P3, Canada \\ ${ }^{c}$ Faculty of Business Administration, Simon Fraser University, Burnaby, BC, V5A 1S6, Canada
}

October 25, 2004

\begin{abstract}
The question of why individual investors want dividends is investigated by submitting a questionnaire to a Dutch investor panel. The respondents indicate that they want dividends partly because the cost of cashing in dividends is lower than the cost of selling shares. Their answers provide strong confirmation for the signaling theories of Bhattacharya (1979) and Miller and Rock (1985). They are inconsistent with the uncertainty resolution theory of Gordon $(1961,1962)$ and the agency theories of Jensen (1986) and Easterbrook (1984). The behavioral finance theory of Shefrin and Statman (1984) is not confirmed for cash dividends but is confirmed for stock dividends. Finally, our results indicate that individual investors do not tend to consume a large part of their dividends. This raises some doubt as to whether a reduction or elimination of dividend taxes will stimulate the economy.
\end{abstract}

JEL classification: G30; G35; G38

Keywords: Dividends; Individual investors; Survey

\footnotetext{
${ }^{*}$ Corresponding author. Tel.: +604-268-6790; fax: +604-291-4920.

E-mail: cveld@sfu.ca (C. Veld).

The authors thank Marcel Das and Mariëlle Klerks for their help with the CentERpanel survey. Furthermore they are grateful to Susan Belden, Abe de Jong, George Frankfurter, David Hirshleifer, Rez Kabir, Skander Lazrak, Elizabeth Maynes, Moshe Milevsky, Terrance Odean, Lynnette Purda, Sara Reiter, Gordon Roberts, Pauline Shum, Yulia Veld-Merkoulova, Marno Verbeek, participants at the APFAconference in Hamburg (August 2002), the Multinational Finance Society Conference in Montreal (June 2003), the Financial Management Conference in Denver (October 2003), the Academy of Financial Service Conference in Denver (October 2003), the Northern Finance Association Conference in St. John's (September 2004), and at seminars at the Erasmus University Rotterdam, HEC Montreal, McMaster University, Simon Fraser University, Tilburg University, University of Calgary, University of Waterloo, and York University for their comments and suggestions. Special thanks go to an anonymous referee and to Jeffry Netter (the editor) for very helpful comments. They also gratefully acknowledge the financial support of the Faculty of Economics and Business Administration at Tilburg University, the Department of Finance at Tilburg University, the CFP Board of Standards in Denver, and Social Sciences and Humanities Research Council of Canada. Part of the work for this paper was done while Chris Robinson was affiliated with the Schulich School of Business at York University and Chris Veld was visiting the Schulich School of Business at York University and was affiliated with the Faculty of Economics and Business Administration at Tilburg University. The usual disclaimer applies.
} 


\section{Introduction}

Our understanding of dividend policy depends on the behavior of individual investors, from the early work of Miller and Modigliani (1961) and Gordon (1961) to the more recent behavioral finance theories. Many empirical papers have documented corporate dividend policy and payments, and have related the policies in various ways to the theories based on the behavior of individual investors. While there appears to be a general agreement that investors like dividends, there has been no empirical study of why individual investors want dividends. We fill that gap by asking individual investors about their attitude towards dividends.

Miller and Modigliani (1961) show that individuals can undo management's decisions on dividend policy in a perfect and complete capital market by either reinvesting dividends or selling off stock, making dividend policy irrelevant. In the United States until recently, as well as in most other countries, dividends have been taxed more heavily than capital gains. The irrelevance theorem in combination with the unfavorable taxation of dividends makes dividends a puzzle. Brealey and Myers (2003) consider the dividend controversy to be one of the "10 unsolved problems in finance."

Fama and French (2001) find that the proportion of U.S. firms paying cash dividends has fallen from $66.5 \%$ in 1978 to $20.8 \%$ in $1999 .{ }^{1}$ Grullon and Michaely (2002) show that firms have gradually substituted repurchases for dividends. ${ }^{2}$ These findings might be a response to the dividend puzzle. Dividends have gained renewed attention recently. On May 23, 2003, the U.S. Congress passed a “tax relief” bill that includes a major change in

\footnotetext{
${ }^{1}$ Baker and Wurgler (2002) argue that throughout history dividends have disappeared and reappeared. Besides that, past market crashes were characterized by a shift of investors towards dividend paying companies. They argue that, since Internet stocks have officially crashed, dividends may reappear in the next few years.

${ }^{2}$ Jagannathan et al. (2000) also indicate that share repurchases are on the rise. However, they argue that share repurchases are not a perfect substitute for cash dividends. They find that dividends are paid by firms with higher "permanent” operating cash flows, while share repurchases are used by firms with higher “temporary” non-operating cash flows.
} 
taxation of investments. ${ }^{3}$ Capital gains and dividends will now be taxed equally at a top rate of $15 \%$, eliminating the tax penalty on dividends. During the period after the bill was proposed and before it passed, Microsoft announced that it would start paying dividends for the first time in its 28-year history. Technology companies such as Cisco and Oracle stated that if dividend taxes were eliminated, they would start paying dividends. This has led to a renewed interest in why investors want dividends.

The modern literature on dividend policy has been strongly dominated by economic modeling approaches, both in developing hypotheses and in empirical investigation of dividend policy. ${ }^{4}$ Brennan (1970) provides an after-tax model of dividend valuation and the Capital Asset Pricing Model that other researchers use. Notably, Black and Scholes (1974) find no evidence of a dividend effect and Litzenberger and Ramaswamy (1979) find a significant effect. Many other papers grapple with this conflict and related hypotheses, but the field of finance has not yet reached a consensus on the effect of dividend policy on firm value. Even though many papers appear later than Black (1976), his belief is still the current opinion (p. 5): "Why do corporations pay dividends? Why do investors pay attention to dividends?... I claim that the answers to these questions are not obvious at all. The harder we look at the dividend picture, the more it seems like a puzzle, with pieces that just don't fit together."

To shed more light on the dividend puzzle, we surveyed a unique Dutch panel of ordinary families who answer questions on personal finance and consumption matters weekly via an organized website/e-mail link. Since this voluntary panel is accustomed to completing questionnaires and most of the panel members will respond, many of the difficulties of survey research are avoided. Furthermore, a demographic profile of the panel members is available, which allows us to better understand the survey responses and test the dividend theories more fully. To the extent that the characteristics of Western investors are similar, we expect our results to be relevant for other Western countries.

\footnotetext{
${ }^{3}$ See the article "House and Senate approve $\$ 350$ billion tax-relief bill” by Shailagh Murray, Wall Street Journal Online, May 23, 2003.

${ }^{4}$ For a review of this literature see e.g. Allen and Michaely (2004), Frankfurter and Wood (2002), and Lease et al. (2000).
} 
We do not include institutional investors in our survey. We are testing the theories developed over more than 40 years relating to individual investor decisions. If institutional investors are acting in place of their clients, then their portfolio decisions will reflect the preferences of their clients. This is particularly true for managers of investment funds, since the income flows directly to the beneficial owners. Our survey looks at individual investors who hold shares directly and/or through investment funds. The indirect holdings through pension plans are not represented.

Conducting research in the Netherlands on dividend preferences has a special advantage, because the new Dutch tax system does not tax dividends and capital gains differently, while the old (pre-2001) system taxed dividends more heavily than capital gains. This tax environment provides us with an excellent setting to test dividend theories by isolating the tax effect on dividends from other considerations. In this regard our results should be more informative than past U.S. survey results, and also provide a preview of investor preferences in the U.S. under the new tax law. ${ }^{5}$

In some previous studies, including Lintner (1956), Baker et al. (1985), Baker et al. (2002), and De Jong et al. (2003), researchers used questionnaires to find out why companies pay dividends. A particularly interesting paper in this vein is Brav et al. (2004), who have surveyed 384 CFOs and treasurers of mostly U.S. companies, and conducted 23 in-depth interviews with executives on their payout policy. They find that financial executives believe that retail investors have a strong preference for dividends, despite the tax disadvantage. Another interesting finding is that financial executives believe that dividends convey management's confidence about the future. However, managers say that they do not pay dividends as a costly signal to convey their firm's true value. Therefore Brav et al. (2004) conclude that they only find modest support for the signaling hypotheses. Their survey finds little support for the agency theories of Easterbrook (1984) and Jensen (1986).

\footnotetext{
${ }^{5}$ The two systems are not identical. The Dutch taxation of investments is now a wealth tax; so timing of realization of capital gains is irrelevant. The US system taxes capital gains on realization and thus a tax timing option still exists that is not applicable to dividends.
} 
The aim of our paper is to determine what individual investors believe about dividend policy. This question is also examined by Brav et al. (2004), but they do so indirectly by asking financial managers for the view of the investors. The managers in their questionnaire believe that individual investors want dividends, but the reasons are not clear. Therefore Brav et al. (2004) conclude, “At this point we can only speculate about what causes individual investors to prefer dividends”. In this paper we try to fill this gap.

We start by summarizing the various hypotheses and conjectures that have been advanced about investor beliefs and behavior regarding corporate dividend policy. We test their validity as descriptions of investor behavior with direct survey research conducted on a sample of Dutch household members who constitute a voluntary panel that answers personal survey questionnaires on family financial and consumer matters every week. From a sample of 2,723 household members we received 555 usable responses from members who hold or recently held common shares and/or investment funds.

Our results unambiguously indicate that individual investors are not indifferent to dividends. The mean score on the question whether they want dividends was answered with an average score of 4.98 on a scale that ranges from 1 (= I do not want dividends) to 7 (= I want dividends), with 4 being the neutral score. $60.5 \%$ of the respondents indicate a score of 5 or above, while only $12.3 \%$ answer 3 or below. Both the mean and the median score on this question are significantly different from 4 at the $1 \%$ level. There is a strong confirmation of the signaling role of dividends. Our results are inconsistent with both the free cash flow theory of Jensen (1986), and the agency theory of Easterbrook (1984). All these results are fairly consistent with Brav et al. (2004).

The results further indicate that transaction costs are an important reason for individuals to like dividends. Investors appear to view dividends as saving transaction costs when they do not reinvest the dividends in the same stocks, e.g. when they want to consume, deposit in a bank account, or reinvest the dividends in a different security. These results are stronger for relatively old, low income and less-educated investors. The uncertainty resolution theory of Gordon $(1961,1962)$ is not confirmed. Investors seem to consider dividend-paying stocks to be more risky than non-dividend paying stocks. Overall, investors do not believe that dividend-paying firms are less likely to manipulate 
earnings, although the notion that dividends work as a guarantee of earnings quality finds some support among older investors.

As one of our most striking results, we find that investors consume significantly less from dividend income than from regular income. Therefore, the behavioral finance theory of Shefrin and Statman (1984) is not confirmed for cash dividends. On the other hand, this theory is confirmed for stock dividends. In case companies cannot pay out a cash dividend, investors prefer the companies to "pay" a stock dividend, rather than no dividends at all, even though in principle stock dividends are no more than stock splits.

Finally, we find that, apart from older and low-income investors, individual investors do not tend to consume a large part of their dividends. Rather, they re-invest their dividend income. This raises some doubt as to whether a reduction or elimination of dividend taxes will stimulate the economy.

The Appendix Table summarizes the results of our survey.

Sections 2 and 3 summarize the theories and hypotheses in the literature on cash and stock dividends respectively. Section 4 describes the research method and data collection. Section 5 describes survey results and discusses how they relate to our hypotheses. Section 6 concludes.

\section{Theories on Why Investors Want Cash Dividends}

\section{a. The Miller and Modigliani (1961) dividend irrelevance theory}

Miller and Modigliani (1961) show that in a perfect and complete capital market the dividend policy of a firm does not affect its value. A stockholder can replicate any desired stream of payments by purchasing and selling equity.

\section{b. Transaction costs}

An investor who wants to receive a regular income from her security holdings has a choice between buying dividend-paying stocks and cashing in the dividends, and buying non-dividend paying stocks and regularly selling part of her portfolio. For a small 
individual investor the transaction costs of cashing in the dividends may be significantly smaller than the transaction costs associated with selling part of the stocks (e.g., Allen and Michaely, 2004).

\section{c. Uncertainty resolution}

Gordon (1961, 1962) argues that outside shareholders prefer a high dividend policy. They prefer a dividend today to a highly uncertain capital gain from a questionable future investment. ${ }^{6}$ A number of studies demonstrate that this model fails if it is posited in a complete and perfect market with investors who behave according to notions of rational behavior (e.g., Miller and Modigliani, 1961; Bhattacharya, 1979). Nonetheless, the original reasoning of Gordon $(1961,1962)$ is still frequently quoted. For example, Ross, Westerfield, and Jaffe (2002) discuss Gordon's reasoning in the latest edition of their textbook. ${ }^{7}$ The model also seems to accord very well with casual observations.

The argument also often comes up in the financial press. It is often stated that the dividend yield takes a substantial part of the total stock return, especially in down markets. For example, in a Wall Street Journal article, a portfolio manager states: "Dividends are now of greater interest to investors - share prices have gone up and down dramatically, but dividends stay fairly steady, and provide some cash income during the bear market." ${ }^{, 99}$ Although this statement is irrational from a theoretical point of view, it can still be the case that a large number of investors want dividends exactly for this reason.

\footnotetext{
${ }^{6}$ This theory is also known as the "bird in the hand" theory. See e.g. Barberis and Thaler (2004).

${ }^{7}$ They disagree with Gordon's reasoning that increased dividends make the firm less risky. Their argument is that a firm's overall cash flows cannot be changed with a change in dividend policy.

${ }^{8}$ See the article "Long in the shadows, dividends take stage" by Erin Schulte, Wall Street Journal Online, April 20, 2002.

${ }^{9}$ It is interesting to notice that Fuller and Goldstein (2003) conclude that dividend-paying stocks have higher returns than non-dividend paying stocks, and that this effect is especially strong in declining markets.
} 


\section{d. A smaller influence from accounting manipulations}

An important reason for companies to pay dividends may be that companies that pay healthy dividends are perceived as being relatively honest and less subject to accounting manipulations. For example, a recent Barron’s article argues: “Embrace stocks that pay healthy dividends. A bird in the hand is better than two in the bush (...). Healthy dividend payments also indicate that companies are generating real earnings rather than cooking the books."10 The aforementioned Wall Street Journal article also states: "Dividends are paid by companies that grow earnings over a longer period of time. [Buying dividendpaying stocks] is a way of getting into growth through the back door, in a lower-risk way." This argument is closely related to the uncertainty resolution argument mentioned under c.

\section{e. Behavioral finance}

Shefrin and Statman (1984) develop "the behavioral life cycle" theory of dividends based on self-control. This argument comes down to investors wanting to restrict themselves from consuming too much in the present. They don't want to dip into capital and, therefore, they only allow themselves to consume current income such as dividends. The effect described by Shefrin and Statman (1984) is especially strong for elderly (retired) investors, as they have little or no labor income and rely more heavily on income from their securities holding. ${ }^{11}$

At first this theory shows some resemblance with Gordon's $(1961,1962)$ theory. However, the theory of Gordon is based on uncertainty towards future dividends, while

\footnotetext{
${ }^{10}$ See the article “After the bubble” by Jonathan Laing, Barron's Online, July 1, 2002.

${ }^{11}$ Shefrin and Statman (1984) argue that their theory is supported by the outcomes of a study from Lease et al. (1976) who find that elderly persons have a stronger preference for dividend paying stocks than younger persons.
} 
the theory of Shefrin and Statman (1984) is based on investors who prefer to consume from dividends instead of capital gains.

\section{f. Free cash flow}

Free cash flow is the cash flow that remains after all positive net present value (NPV) projects are undertaken. According to the overinvestment theory of Jensen (1986), managers aim to expand the size of the firm, and thus may take on negative NPV projects instead of paying dividends. Managers consider a larger firm to be more prestigious and to pay them more. This is obviously not in the interest of the existing shareholders. Black (1976) also argues that paying dividends can mitigate a potential overinvestment problem, because they reduce the amount of free cash flow. This theory is difficult to test in the context of our research. The reason is that it is difficult to convey the notion of a negative net present value project to individual investors who are not aware of finance theory. One possible way to test this theory is by linking free cash flow to down markets or economic downturns, on the assumption that there are fewer growth opportunities in such circumstances.

\section{g. Agency costs}

Even if a firm does not have free cash flow, dividend payments can still be useful for the shareholders in order to control the overinvestment problem. Easterbrook (1984) argues that dividends reduce the overinvestment problem because the payment of dividends increases the frequency with which firms have to go to equity markets in order to raise additional capital. In the process of attracting new equity, firms subject themselves to the monitoring and disciplining of these markets. ${ }^{12}$ This lowers agency costs. A share repurchase creates the same monitoring effect.

\footnotetext{
${ }^{12}$ See also the article: “The macro investor” by Steve Liesman, Wall Street Journal Online, September
} 5, 2002. 
Corporate governance operates somewhat differently in the Netherlands than in the Anglo-Saxon systems. Dutch companies with over 100 employees and over 11.4 million Euros in shareholders' equity must use a "structured regime" of governance, and this includes almost all of the companies that are listed or that Dutch investment funds could invest in. The shareholders initially establish a supervisory board and a management board. The shareholders have no vote on how the supervisory board changes its membership over time, nor do they have any vote on management actions. The shareholders do vote on mergers and acquisitions, and dividend policy. The supervisory board can introduce various forms of dual class equity that make hostile takeovers almost impossible, again without shareholder vote.

The supervisory board and the management board work closely together normally. These governance mechanisms therefore tend to entrench management, whether the shares are widely-held or not. De Jong et al. (2004) provide more discussion of this system and its effects on share value. For our study, the implication is that if dividend policy is an effective means of reducing the agency costs of management-ownership separation, then dividends should be particularly important for Dutch shareholders, since they have very little other power to exercise over management.

\section{h. Signaling}

Bhattacharya (1979) and Miller and Rock (1985) argue that information asymmetries between firms and outside shareholders may induce a signaling role for dividends. They show that dividend payments communicate private information in a fully revealing manner. The most important element in their theory is that firms have to pay out funds regularly. Therefore, a similar reasoning applies to recurrent share buy-backs. Recent literature suggests that the signaling role of dividends depends on the corporate governance structure. ${ }^{13}$ Dutch companies are mostly held by large shareholders (De Jong

\footnotetext{
${ }^{13}$ Gugler (2003) finds that state-controlled firms in Austria "smooth" dividends, while family-owned firms do not show such smoothing. Gugler and Yurtoglu (2003) find that German companies where the ownership and control structures make the expropriation of minority shareholders more likely than for
} 
et al., 2001). However, this does not necessarily mean that large shareholders are better informed than small shareholders. Dutch law requires that all shareholders should receive the same information from the management of the firm. It is illegal to inform large shareholders better than small shareholders. This has led to court cases in the Netherlands. The CEO of the Dutch Orange Fund had to resign in the past as a result of informing large shareholders better than small shareholders. Furthermore, even if large shareholders are somehow better informed than small shareholders, they are not nearly as well informed as the managers. The accounting scandal with the Dutch supermarket company Ahold demonstrates how badly informed large shareholders can be. We therefore believe that there is substantial information asymmetry between management and (large) shareholders in the Netherlands.

\section{i. The choice between cash dividends and share buy-backs}

Common stock repurchase is a well-known alternative to cash dividends. Both ways of paying out cash are useful to mitigate the agency problems that are raised by Easterbrook (1984) and Jensen (1986).

A large number of academic papers find that share buy-backs are especially useful to signal that the stock price of the company that buys back its shares is undervalued. A number of studies including Comment and Jarrell (1991) and Ikenberry et al. (1995, 2000) find that share buy-back announcements are associated with significantly positive abnormal returns. Ikenberry et al. (1995, 2000) have also analyzed the long-run performance of US and Canadian companies after share buy-backs. These studies find a significantly positive long-run positive abnormal return. These results support the undervaluation hypothesis for share buy-backs.

\section{j. Taxes}

other firms exhibit significantly larger negative wealth effects. Finally, Goergen et al. (2004) find that German firms with banks as their major shareholders are more willing to omit their dividends than firms controlled by other types of shareholders. 
The subject of dividend policy has received a lot of attention in the United States. The reason for this is that in the U.S. (and most other countries) dividends are taxed more highly than capital gains. The difference is material, and thus provides a substantial incentive for investors to prefer to generate income by selling some of their shares and to receive no dividends. This situation came to an end when the tax cut package (the scaleddown version of the Bush proposal unveiled in January 2003) was passed in May 2003. Under the new legislation, dividends and capital gains will be taxed at the same rate of $15 \%$ for the next few years.

Under the Dutch income tax system, since January 1, 2001, rational individual investors in the Netherlands are entirely indifferent between receiving dividends and capital gains. ${ }^{14}$ The tax system now levies what is effectively a wealth tax, applied to the market value of capital. Capital is basically cash and portfolio investments. The tax rate is a flat $1.2 \%$ of the asset value, regardless of the dividends, interest and capital gains received during the year. In the old tax system prevailing before January 1, 2001, dividends were treated as ordinary income and were taxed at a progressive rate. In the old system, capital gains were not taxed at all. ${ }^{15}$

There is a withholding tax (dividendbelasting) of $25 \%$ on dividends. This withholding tax was levied both in the current and in the old tax system, and would be refunded if the taxpayer completed a tax return.

The taxation of investment funds deserves special attention. Both in the current and in the previous tax system, investment funds can apply for the status of investment institution (beleggingsinstelling). If this status is granted the investment fund pays no corporate tax. However, it also has the obligation to pay out its profits within eight months after the end of the book year. Given the equal treatment of dividends and capital gains in the current system, it has become increasingly beneficial for Dutch investment

\footnotetext{
${ }^{14}$ See Meussen (2000) for a detailed description of the Dutch income tax system that is operational since 2001.

${ }^{15}$ An extensive description of the taxation of dividends in the Netherlands, both in the new and in the old income tax systems, is on request available from the authors.
} 
funds to apply for this status. This also means that investment funds are more likely to pay dividends than ordinary exchange-listed companies.

\section{Theories on Why Investors Want Stock Dividends}

\section{k. Stock dividends as small stock splits}

An issue that is closely related to that of cash dividends is the question of why some companies "pay" stock dividends. As every standard textbook in Finance teaches us, stock dividends are nothing more than a small stock split. DeBondt and Thaler (1995) refer to stock dividends as one of the big anomalies in finance.

\section{l. Transaction costs}

Stock dividends may have an advantage over cash dividends because they may carry lower transaction costs. This is the case if the ultimate goal of the investor is to re-invest the dividends. With a stock dividend, the dividend is effectively re-invested in the same stock. With a cash dividend, transaction costs are incurred to re-invest the money in stocks. Again, it has to be noticed that a stock dividend is not a real dividend. However, for an investor who sees a stock dividend as a real dividend, and who wants to re-invest her money, stock dividends may reduce transaction costs. It also has to be noticed that with a cash dividend, an investor can choose to invest her money in another stock. This is not the case with a stock dividend. Finally, a stock dividend may carry a disadvantage if the investor owns an odd number of shares. For example, an investor holding 113 shares might receive one share for 100 stock dividends. This would mean that she either has to sell 13 stock dividends or that she would have to buy 87 stock dividends. This might make a stock dividend relatively expensive for a small investor.

\section{m. Taxes}


In the old Dutch tax system, stock dividends were not taxed if they were paid out of the additional paid-up reserve (agioreserve). It should be noted that the fact that stock dividends were tax-free under the old tax system did not carry as big of an advantage as seems at first. Stock dividends are nothing more than a stock split and should not be taxed in the first place. In the new tax system, the tax indifference that applies to cash dividends also applies to stock dividends.

\section{n. Behavioral finance}

Shefrin and Statman (1984) argue that there are behavioral reasons to "pay" stock dividends. These reasons are especially compelling if the company does not want to pay a cash dividend, e.g. because it does not have free cash flow. They argue that stock dividends are labeled as dividends. Therefore, an investor who sells off and subsequently consumes her stock dividend does not break the mental accounting rule to not consume out of capital. Furthermore, stock dividends that are kept in portfolio are considered differently from the original stocks. The reason for this is that many investors think in terms of gains and losses. They consider the price for which they acquired the share of common stock. This price is different for the original share and for the share that was acquired with the stock dividend.

\section{Empirical Methods and the Data}

\subsection{Survey Methods and CentER Panel}

We surveyed individual investors to test the theories discussed in the previous two sections. Survey-based research is becoming more common in finance. Surveys complement research based on large samples and clinical studies, particularly for a question like dividend policy where the beliefs of investors are the basis for most of the theoretical models. Graham and Harvey (2001) argue that large-sample studies often have weaknesses related to variable specification and the inability to ask qualitative questions. Results of clinical studies on the other hand are often sample-specific. Survey-based 
research offers a balance between these two approaches. Graham and Harvey (2001) also recognize a few problems associated with survey-based research. The first is that the respondents may not be representative of the population. The second is that survey questions may be misunderstood. The third potential problem is that surveys measure beliefs and not necessarily actions.

Dividend policy is one of the few areas in finance where survey research has been used fairly frequently. Examples include Lintner (1956), Baker et al. (1985), and Brav et al. (2004). However, all these studies have focused on managers of companies. As far as we know there is not a single study that has asked individual investors about dividends.

The survey used in this paper consists of a questionnaire submitted to the internetbased panel of CentERdata ${ }^{16}$ at Tilburg University in the Netherlands. This panel, which consists of members from more than 2,000 households, was established in 1991. However, there is no need to have a personal computer with an Internet connection. Households that do not have access to the Internet are provided with a so-called NetBox with which a connection to the Internet can be established via a telephone line and a television set. If the household does not have a television, CentERdata provides one. All households can call a helpdesk or ask for technical support from home. The panel is recruited by telephone, so the recruiting of the panel is independent of whether or not households have Internet access. The panel is kept representative of the Dutch population with respect to a number of demographics. In other words, the average panel member has the same experiences and knowledge as the average person living in the Netherlands. The members of the panel are interviewed each week on a number of issues that deal with financial matters. Clients of the panel are businesses and researchers at universities. Previous finance research with this panel has mostly focused on household portfolios. ${ }^{17}$

\footnotetext{
${ }^{16}$ CentERdata is the division for applied research of the Center for Economic Research (CentER). CentER is the research school of the Faculty of Economics and Business Administration of Tilburg University in the Netherlands. Information about the panel can be found at http://www.centerdata.uvt.nl

${ }^{17}$ For example, Donkers and Van Soest (1999) and Donkers et al. (2003) have used the panel in order to elicit information about subjective measures of household preferences, financial decisions and risk attitudes.
} 


\subsection{The Questionnaire}

We have made large efforts to avoid the potential problems that are associated with the use of surveys. First, the problem that the respondents may not be representative of the population is avoided by the use of the CentER panel. Second, we ask several questions for each of the theories in order to limit the possibility that our questions are misunderstood. Finally, while it is true that surveys measure beliefs rather than actions, we do not view this as a problem, since beliefs are what we want to measure.

The use of this panel has great advantages over the more usual survey/questionnaire research. The professional experience of CentER staff provides assurance that the mechanical aspects of questionnaire distribution, confidentiality and data collection run smoothly. The final form of the questionnaire is largely standardized so that the respondents do not have to accustom themselves to new formats for each separate research project. The respondents are accustomed to answering questions from CentERdata and thus the error rate should be low. Although panel members are not obliged to fill in all the questionnaires, the response rate is guaranteed to be very high. Furthermore it is possible to link the results to demographic factors (such as education, income and age). The identity of respondents is kept confidential, and the respondents know this, which makes them more likely to answer truthfully. Finally, it is possible to test for non-response bias more effectively than is possible with ordinary surveys.

We did not conduct personal interviews as Brav et al. (2004) did. The confidential nature of the respondent database precludes us interviewing any of them. Since the questions we are asking are directed to specific hypotheses about dividend preferences, we were not looking for the open-ended, less circumscribed evidence that personal interviews are better at capturing. If we had wanted to determine some new theory of why investors want dividends, we might have considered grounded theory. ${ }^{18}$ We developed the questions to be as easy to answer as possible, to make the responses useful.

\footnotetext{
${ }^{18}$ Glaser and Strauss (1967) develop the technique of grounded theory. The researcher who has only a general idea of the topic she wishes to investigate conducts a number of substantial interviews with persons
} 
The English language version of the survey instrument is included in the Appendix. We originally created the questionnaire in English as it appears here, but the version sent to the respondents was translated into Dutch. ${ }^{19}$

While there is a substantial literature on survey and questionnaire design, most of the difficult issues do not arise in our work. There is no politically or socially desirable answer to bias respondents. The only challenge is to design the questions in such a way that captures the essence of the hypotheses that were put forward in Sections 2 and 3. Therefore the questions have to be couched in plain, unambiguous language that the respondents understand. For this reason, the questions were designed in cooperation with the researchers from CentERdata who administer the panel and who have a lot of experience with conducting this type of research.

Questions 1-4 determine whether the respondents own, or have owned within the last three years, shares in companies and/or investment funds. If they have not, we exclude them from the rest of the survey. Questions 5-26 investigate the various hypotheses and theories about cash dividends we advanced in the previous section. Question 27 asks a question unique to the Dutch tax system. Questions 28-32 ask questions related to stock dividends.

\subsection{Statistical Inference}

These responses are both presented for the whole sample and for sub-samples according to demographic statistics, i.e., age, income and education. Most of the questions are asked on a scale of 1 to 7 , with 4 as the neutral score. Respondents could also answer 8 for "Don’t know/No opinion” and these responses are omitted from the statistics.

who should know or embody the principles of some particular problem or question. From these interviews, the researcher creates one or more hypotheses about behavior that she can test on larger numbers of subjects or sites. For example, this is essentially the method that Lintner (1956) uses. Since we are testing established theories in the field, we go directly to the larger sample.

${ }^{19}$ The Dutch version of the questionnaire is, on request, available from the authors. 
For Questions 5-32, we test whether the mean and median responses are significantly different from the neutral response, and whether the responses from demographic groups are significantly different. Based on the Shapiro-Wilk statistic, we cannot reject the null hypothesis that the response rankings are normally distributed at the 0.01-level, for all questions. However, we still use a non-parametric two-sample test for the median responses.

For most questions with a neutral score of 4 , we test whether the mean response is different from 4 using $t$-statistics. We test whether the median is different from 4 by taking the difference between the response and 4 , and assessing whether the median difference is different from 0 using a two-tail Fisher sign test, with statistical significance reflected in the binomial $p$-value. We use a two-sample $t$-test to test whether the mean responses are different between demographic groups. The corresponding differences in medians are assessed using a non-parametric two-sample median test.

For Question 27, which asks for a binomial response (=1 if “yes”, 0 if "no”), we test whether the response is different from 0.5 using a t-test for the mean, and a sign test for the median. For the difference in mean between demographic groups, we use a $Z$-test for the difference in proportions. The difference in median between groups is still assessed using a two-sample median test.

\section{Results}

\subsection{Overview of Survey Respondents}

The questionnaire based on the theories discussed in Sections 2 and 3 was presented to the 2,723 members of the panel of CentERdata on the weekend of October 4, 2002. ${ }^{20}$

\footnotetext{
${ }^{20}$ For this purpose all panel members of 16 years and older were selected. This allows the possibility that multiple persons from one household answer the questionnaire. As a robustness test we have also run the analysis with only one member from each household in the responses. In that case the valid investor sample is reduced from 555 to 507. However, our conclusions remain unchanged, although there are occasional minor changes in statistical levels. These results are available on request from the authors.
} 
These members had the opportunity to fill out the questionnaire from 17.00 hours on Friday October 4, 2002 to 24.00 hours on Tuesday October 8. In total 2,035 respondents filled out the questionnaire (74.7\%). This makes the number of non-respondents equal to 688. Out of the 2,035 respondents, 555 panel members own or used to own shares in exchange-listed companies and/or investment funds. Table 1 gives the summary demographic statistics of the survey respondents.

[Please insert Table 1 here]

Table 1 indicates that a significant proportion of the investors (42.5\%) either own (or used to own) stocks and investment funds. The remainder of the investors own or used to own only stocks (18.6\%) or only investment funds (38.9\%). Furthermore, the majority of the investors are below age $55(60 \%)$, earn a low income $(68.5 \%)^{21}$ and have no university education (72.8\%). We have also calculated the correlations between the different categories. As can be expected, given education trends in most OECD countries, age and education are negatively correlated with a correlation of -0.099 . At the same time, older investors are also wealthier, with a correlation between age and income level of 0.088 . Finally, income and education are positively correlated with a correlation of 0.318. Figure 1 gives the demographic distributions of the survey respondents.

[Please insert Figure 1 here]

It can be concluded from Figure 1 that on average investors are older, have higher income and are better educated than non-investors, which is what we would expect.

Following suggestions by the referee we have also submitted two small additional questionnaires to the panel. The first additional survey was submitted to the panel in the weekend of October 7, 2003. The second additional survey was submitted to the panel in the weekend of March 13, 2004. These additional surveys will from now on be referred to as the first and second follow-up survey and are discussed in the next subsection.

\subsection{Results for Cash Dividends}

\footnotetext{
${ }^{21}$ From now on a low income is defined as a monthly gross income lower than 3,000 Euro. A high income is defined as a monthly gross income higher than 3,000 Euro.
} 
Table 2 includes the responses to the questions on cash dividends.

[Please insert Table 2 here]

Tables 2-5 present the result of tests on both the theories, and whether the different demographic groups have significantly different attitudes towards the theories. Therefore, the significance of results in the first column, "All Investors," measures whether the mean and median are significantly different from 4 . The results in the remaining columns should be read in pairs, where the test is whether difference between the means/medians of the two groups (e.g. “Age Below 55” versus “Age Above 55”) is statistically significant ${ }^{22}$.

The first question in Table 2 (Question 7) asks whether investors like their stocks to pay dividends, with possible answers from 1 for "I do not want dividends" to 7 for "I want dividends”. A score equal to 4 means that the investor is neutral between receiving dividends or not. Both the whole sample and all the sub-samples show means and medians significantly greater than 4 . The mean for the whole sample is 4.98 with a tvalue of 14.04 . The median is 5 with a binomial $p$ of 0.0000 . The percentage above the neutral score of $4(60.5 \%)$ is much larger than the percentage below 4 (12.3\%). This justifies the conclusion that investors want dividends.

The preference for dividends is greater among investors older than 55 (hereafter, the “older investors”), compared with younger investors. However, both categories show highly significant means and medians. Both the result that retail investors want dividends and the result that this is especially true for older investors are in line with the survey results of Brav et al. (2004). They find that some CFOs state that some of their investors are the "gray-haired set" or "mom and pop" investors.

The second theory tested in this table is whether investors want dividends for reasons of transaction costs. The mean score for this question is 4.20 with a $t$-statistic of 2.79 . Only $20.5 \%$ of the respondents indicate a score lower than 4 , while $33.3 \%$ of the respondents indicate a score higher than 4 . The median is 4 and is significantly different

\footnotetext{
${ }^{22}$ We have also looked at the modes for each group. Most of the time the mode and the median are identical. Even when they are different, the mode responses between groups are almost always the same. Therefore we have not reported the modes in the text.
} 
from 4, on a significance level of 0.0002 . At first sight it looks strange that a median score of 4 is significantly different from the neutral score of 4 . This can be explained by the large difference in percentages of observations above or below 4. Despite the fact that the mean and median score of the whole sample are significantly different from the neutral scores, there are remarkable differences between the different demographic groups. Old investors, low-income investors, and investors without university education all have a preference for dividends because of transaction costs. On the other hand, young investors and investors with a high income and/or university education have less interest in dividends based on transaction costs. For each of these categorizations the difference in means between the groups is significant. For the income and education categories the difference in the median scores is also significantly different from zero.

The third theory is the uncertainty resolution theory that was originally suggested by Gordon (1961, 1962). According to this theory investors prefer dividend-paying stocks, because they are perceived to be less risky. The result for Question 9 for the whole sample suggests the opposite result. Investors perceive dividend paying stocks to be more risky: the mean score is 4.13 with a $t$-value of 2.37. Questions 10 and 11 also confirm this result. Apparently, investors perceive high dividend yield stocks to be more risky than low dividend yield stocks. This result may be explained by the level of the stock index in the research period. In the period from July 2002 to October 2002 the index of the Amsterdam Stock Exchange, the AEX-index, dropped to a level below 300 points. This was the lowest level in 7 years. At the same time most of the companies in the index maintained their old dividend levels. As a consequence, the dividend yield rose strongly, especially for badly performing stocks. This may have contributed to the perception that high dividend yield stocks are riskier. Baker et al. (2002) surveyed managers of NASDAQ companies that consistently pay cash dividends. They also find no evidence in favor of the uncertainty resolution theory.

The conjecture that dividends are a safeguard against accounting manipulations is not generally supported by the answers to Questions 12 and 13. In Question 12 for the whole sample, investors are neutral on the question of dividends as offering more certainty about future earnings. In Question 13, the investors reject the idea that dividends signal 
'real' earnings. Both questions show the interesting result that younger investors strongly reject the conjecture, while older investors in Question 12 marginally agree with the idea.

The referee suggested that these responses might differ if the nationality of the investments is considered - investors would be more wary of relying on financial statements from a country with somewhat weaker accounting and auditing standards. In response to this idea, we included a question in the first follow-up survey in order to determine for a small subset whether or not they held $10 \%$ or more of the portfolio in US stocks, thereby implicitly treating the US as having different standards from other countries. We do not find a significant difference between these two groups in their responses to Questions 12 and $13 .{ }^{23}$

The results for Jensen's (1986) free cash flow theory are remarkable. Both the results for the whole sample and for the individual sub-samples are inconsistent with this theory. For both Questions 17 and 18, the results for the whole sample and for all the subsamples show mean scores that are well below 4 . The results indicate that individual investors do not see dividends as a way to control for possible overinvestment tendencies by management. It should be mentioned that we only look at one side of the free cash flow theory, i.e. the possibility to control the tendency for over-investment by the disciplining role of dividends. We do not look at other possibilities to control for this tendency, such as the disciplining role of debt.

Our results are also inconsistent with the agency theory of Easterbrook (1984). Both Question 19 and Question 20 show very low means and medians. For example, the median score for both questions is never above 2. Moreover, these means and medians are strongly significant. This result holds for all demographic sub-samples. These results suggest that individual investors have a preference for management to use internal funds to finance capital budgeting projects, in line with the pecking order theory of Myers and

\footnotetext{
${ }^{23}$ We did not ask them Questions 12 and 13 again. There is a unique code for each respondent, and so we could match the response on the new questionnaire regarding nationality of stock holdings with the person's original response to these two questions.
} 
Majluf (1984). ${ }^{24}$ This finding confirms the survey results of Baker et al. (2002) and Brav et al. (2004). Both surveys indicate that there is little or no support for the agency models. In the context of the Netherlands, where dividend policy is one of the few levers shareholders control, this finding also implies that dividends are unlikely to be an effective governance mechanism in other jurisdictions like the US, where shareholders have more formal rights and the market for corporate control is more active.

In contrast to the agency theories, we see a very strong confirmation of the signaling theory of Bhattacharya (1979) and Miller and Rock (1985). All means and medians are significant, indicating that individual investors believe that dividend payments contain a signal about the profitability of the firm. ${ }^{25}$ This result gives justification to management's "sticky" dividend policy in good and bad times. Like most of our results, this result is in line with Brav et al. (2004). They also find that financial executives believe that dividends convey confidence in the future. However, in addition they find that executives do not deliberately use dividends as a signal. We have not tested the latter result in our paper, since it is difficult for individual investors to ascertain whether managers deliberately use dividend policy to signal the true value of the firm.

\footnotetext{
${ }^{24}$ Although it can also be noticed that investors have greater difficulties with the firm borrowing funds than with the firm issuing new stock in order to pay for a dividend. The mean result for the "borrowing question” (Question 20) is 2.03 and the mean result for the "issuing stock” question (Question 21) is 2.40. This result is not consistent with the pecking order theory, since that theory states that companies prefer borrowing to issuing new stock.

${ }^{25}$ The strong significance of this theory is at first remarkable given that the Dutch tax system no longer discriminates in favor of capital gains as compared to dividends. This means that taxes no longer impose a cost of signaling via dividends. However, dividends are still costly if the firm needs to raise funds from the capital markets later on, because of security issuance fees as well as the negative stock market reactions to dividend cuts. Allen and Michaely (2004) summarize evidence of such cuts for the United States. This effect also occurs for the Netherlands (Dorsman, 1988). Furthermore, both sources indicate that the stock market reactions to dividend cuts are stronger than those for dividend increases.
} 
There is a seeming inconsistency between the belief that dividend-paying stocks are riskier than non-dividend paying stocks on one hand, and the belief that dividends are a good signal of the profitability of the firm on the other hand. However, it is worth noting here that it is the change in dividend payments, not the level of dividends that signals future cash flow prospects. In this regard, our result that investors believe that dividendpaying stocks are riskier than non-dividend paying stocks (from Questions 9 and 10) is not inconsistent with the signaling result. Investors can view a firm to be of high risk if it is paying high dividends; on the other hand, if that firm increases dividend payments, this is viewed as a positive signal for its future profitability. Similarly, the finding that many investors don't feel more certain about the earnings prospects of dividend-paying firms (from Question 12) is not necessarily at odds with the signaling effects of dividends either. One interpretation is that investors think that a high current dividend payment may drain the firm's cash resources so that future earnings are uncertain. But the same investors are persuaded to think positively about future earnings if the firm decides to increase dividends.

Even though both dividends and share buy-backs are ways of paying money back to shareholders, investors do not see share buy-backs as equivalent to dividends. Question 23 shows that, for the whole sample, investors do not want companies to substitute dividends for share buy-backs. The question how they would value a company decision to stop paying dividends and instead buying back shares, with a score of 1 representing “extremely negative” and a score of 7 representing "extremely positive” leads to a mean score of 3.81 with a t-value of $-2.67 .^{26}$ Note that high-income investors have a bigger preference for share buy-backs to dividends compared to small investors, consistent with the finding from Questions 7 and 8 that small investors have a stronger preference for dividends. Question 24 shows that investors on average perceive a share buy-back to be a

\footnotetext{
${ }^{26}$ This finding is in line with the results of Brav et al. (2004). They find that financial executives believe that individual investors have a preference for cash dividends. They also find that institutional investors are indifferent between cash dividends and share repurchases. Since our study only focuses on individual investors we cannot test the last mentioned claim.
} 
signal that the stock is undervalued. This confirms results by e.g. Comment and Jarrell (1991) and Ikenberry et al. (1995, 2000).

Individual investors definitely do not have a preference for dividends for tax reasons. Question 26 indicates that this is true under the old tax regime. This is not surprising, since in this regime dividends were taxed and capital gains were not. Strangely enough, the dislike of dividends seems to be stronger in the new system. The mean response drops from 3.79 (Question 26) to 3.60 (Question 25). This is remarkable, since under the new system, theoretically investors would be expected to be neutral to dividends for tax reasons. Question 27 checks whether investors have handed in a tax form for 2001. Such a form is necessary for investors to get their $25 \%$ dividend surtax reimbursed. We find that $60 \%$ of the investors did not hand in such a form. In order to find out why some investors did not claim back the dividend taxes withheld, we have included an additional question on this topic in the second follow-up survey. This question was only asked to respondents who did not submit a tax form for the year 2001.

This follow-up question was answered by 252 respondents. Of these respondents, $22.6 \%$ indicated that they did not hand in a tax form because they did not receive cash dividends even though they held stocks. Another 8.2\% indicated that they were not aware of the fact that it was possible to get dividend taxes reimbursed. More importantly, 26.6\% of the respondents stated that they did not find it worth their time to claim back the dividend taxes, since these taxes were very low. Among other respondents, $0.4 \%$ did not find it worth their time to fill in the tax form even though the dividend taxes were substantial, 3.2\% simply forgot it, 3.6\% believed that the dividend taxes were more than canceled out by other taxable items such as income from other sources, and the remaining 26.2\% did not have an opinion on this question. The answers to this question clearly indicate that there are costs for some investors to receive dividends. These costs consist of foregone dividend taxes. These taxes are foregone, because the investors have to make an effort to fill in a tax form. Nonetheless, the costs in the form of foregone dividend tax reimbursement do not offset the benefits that dividends bring about in transaction cost savings, as Question 8 indicates.

Table 3 includes the responses to the general dividend questions.

[Please insert Table 3 here] 
More specifically, these questions ask why investors hold stocks in investment funds in addition to individual companies (Question 5) or why they hold stocks in investment funds without having stocks in individual companies (Question 6). The assumption behind both questions is that investment funds pay more reliable dividends (because of tax reasons). If the answers of both questions are taken together, we find that dividends are valued more by older, less-educated and low-income investors. These results are in line with the answers to the question on the transaction costs (Question 8). They give further rise to the idea that a part of our respondents want dividends because of transaction costs.

The responses to the behavioral finance questions are included in Table 4.

[Please insert Table 4 here]

In Table 4 we test whether investors want dividends, because they prefer to consume from dividends rather than from capital gains. This notion was put forward first by Shefrin and Statman (1984). In Question 16 we ask whether investors, for consumption purposes, would sell their stocks in a company that has always paid a dividend, if the management of that company would decide not to pay a dividend anymore. From Question 16 we find that the mean score is 2.87 , which means that investors tend to disagree with the given statement. Both the mean and the median are significantly different from 4 . This holds both for the whole sample and for all the sub-samples. The answer to this question is unfavorable for the behavioral finance theory. However, it can also be the case that investors have different reasons for not wanting to sell the stocks in such companies. For example, they might find the transaction costs of selling such stocks too high.

Questions 14 and 15 are different from most of the other questions that are included in the questionnaire. In these questions we ask for the percentage of dividends and regular salary respectively that the investors use for consumption purposes. In order to facilitate the respondents we put the percentages in five categories, ranging from 1 ( $=0$ to 20 percent) to 5 (= 80 to 100 percent). The mean score for the consumption from dividends is only 1.83. The mean score for regular income is 3.13. The difference between these two categories (-1.44) is significantly different from zero at the $1 \%$ level. 
This indicates that investors consume more out of their regular salary than out of dividends. ${ }^{27}$

According to Shefrin and Statman (1984), older investors have a greater preference for dividends than younger investors do, because they receive less regular salary. Brav et al. (2004) show that this is also the executives' opinion. The CFOs interviewed in their study believe that retail investors (at least the elderly) consume directly from their dividend receipts. In our sample, the mean consumption out of dividends is 2.00 for older investors and 1.69 for younger investors. This difference is significant at the $5 \%$ level. This is also consistent with the finding that these two categories of investors have a preference for dividends because of transaction costs. However, we also find that older investors consume more out of their regular salary than younger investors. The mean score is 3.37 for the older investors and 2.95 for the younger investors. The difference between the age groups is significant at the $1 \%$ level. However, the difference between Questions 14 and 15 is -1.44 for both younger and older investors. Hence we find that the notion amongst executives that elderly people consume from their dividend receipts is not confirmed. Brav et al. (2004) try to find out from the executives why individual investors want dividends. However, they do not receive a concrete explanation. The authors mention four possible explanations: agency, signaling, behavioral factors and transaction costs. Based on the results that we have discussed before, we believe that the signaling and the transaction costs explanations have the highest validity.

Apart from the older and low-income investors it is clear that most investors do not consume out of their dividends. The answers to Questions 14 and 15 in combination with the answers to Question 8 suggest that these investors want cash dividends for transaction cost reasons, even though they do not consume most of the dividends. This does not need to be contradictory, because as long as investors do not reinvest all of the cash dividends in the same stocks, dividends always save the transaction costs of selling shares. In order

\footnotetext{
${ }^{27}$ The referee questioned whether we would get the same result if we had asked for actual percentages, rather than scales. In our first follow-up survey we asked the respondents for the actual percentages. The response was a mean of $22.4 \%$ consumption from dividends vs. $58.6 \%$ consumption from regular income. These means were significantly different at the $1 \%$ level.
} 
to confirm this, we have included a question in the second follow-up survey in which we ask the respondents what they generally do with the cash dividends that they receive (multiple answers were possible). In line with previously reported results, only $12.9 \%$ of the respondents indicate that they use their dividends for consumption. A fairly large number of respondents (36.5\%) indicate that they reinvest dividends in the same stocks. However, there are plenty of reasons (besides consumption) why dividends save transaction costs: $39.1 \%$ of investors deposit the dividends received in a bank account, $6.8 \%$ state that they invest dividends in different stocks, and there are also investors who use dividends in other ways such as investing in other securities such as bonds (4.5\%) or paying back (mortgage) loans (1.2\%).

Our results on Questions 14 and 15 are in line with an earlier study of Winnett and Lewis (1995). In order to test whether Dutch investors use different mental accounts as hypothesized by Shefrin and Thaler (1988), they asked shareholders in the CentERpanel whether they would consume out of a substantial capital gain or a substantial rise in dividends in the current as compared with the previous year. The authors found that there was no significant difference between the propensities to save from capital gains and increased dividends, and over 80\% claimed that they would spend none of the increment to their wealth. Both our results and those of Winnett and Lewis (1995) suggest that there is a distinction between the treatment of income from capital and from other sources, such as labor.

Finally, the results of Questions 14 and 15 are interesting in light of the tax cut package of the Bush administration. In an article in The Wall Street Journal Online of January 7, 2003, it is stated: "One of the chief initiatives [of the Bush proposal] is to eliminate income taxes on corporate dividends, arguing that the corporations were already taxed on their profits. This double taxation, the White House says, saps investors of cash they could otherwise be spending to bolster the economy." Our results show that investors actually do not spend dividends as much as ordinary income. Instead they seem to re-invest most of the dividends. However, a caveat is in order here. In the U.S. tax system, dividends are paid to shareholders gross, i.e., with no personal income tax deducted. Shareholders then report the dividends on their tax return each year. The new tax code would therefore mean that investors still receive the same amount of dividends, 
but they will pay less in taxes at the end of the year. Still, our result offers direct evidence on the often-made statement that the marginal propensity to consume is significantly lower, on average, for most people who own shares. The conclusion that this dividend tax cut will only have second-order effects on the payout decision is also reached by Brav et al. (2004).

\subsection{Results on Stock Dividends}

The responses to the questions on stock dividends are included in Table 5.

[Please insert Table 5 here]

The first question in Table 5 asks whether respondents consider stock dividends to be more like stock splits (response possibility 7) or like cash dividends (response possibility 1). The textbook answer would naturally be 7 . The mean score for the whole sample is 4.16. The $t$-statistic is 2.04 . The median score is 4 . The median is significantly different from four at the $5 \%$ level. The number of scores higher than 4 is $39.8 \%$ versus only $27.7 \%$ that is lower than 4 . It can be concluded that there is only a slight recognition that a stock dividend is more like a stock split than like a cash dividend. This either means that investors do not understand stock dividends or that there is a psychological explanation. The difference in means for the sub-samples of high income and universityeducated investors is not significantly different from zero. It is especially remarkable that investors with university education do not understand the nature of stock dividends. However, the differences in scores between the different education and income groups are also not significant.

The second question on stock dividends (Question 29) shows that when only considering transaction costs, on average, investors prefer stock dividends compared to cash dividends. This result suggests that most investors reinvest their dividends, and further confirms the earlier conclusion we draw from Questions 8, 14 and 15. As mentioned in Section 3, stock dividends are a costless way of reinvesting dividends in the same stocks. However, as mentioned before, this assumes that investors consider stock dividends as real dividends, not as stock splits. 
According to the answers to Question 30, investors are indifferent between cash and stock dividends for tax reasons. The average answer to Question 31 (4.56) shows that under the old tax system, investors had a preference for stock dividends over cash dividends for tax reasons. All sub-samples for this question show a score that is significantly higher than 4 . This applies both to the means and to the medians. Finally, Question 32 shows that investors prefer a stock dividend to no dividend at all. Again, this applies for all sub-samples. This notion is stronger for respondents without university education than for respondents with university education.

\subsection{Robustness Checks}

Answers by respondents who do not want to receive dividends or who are indifferent may not be valid in testing theories of why dividends are relevant. These investors answered 1, 2, 3 or 4 to Question 7 (Do you like your stocks to pay dividends? 1= I do not want dividends; 4 = neutral; $7=$ I do want dividends). Investors who do not want

dividends, for whatever reason, or who are indifferent, may answer the later questions relating to the theories differently and thus provide spurious evidence. No a priori theoretical or empirical basis exists for this distinction, but it does seem possible. We believe that investors, who prefer not to receive dividends or are indifferent, should still have valid opinions on the theories for and against dividends, since they are equally part of the market for shares. However, we tested to see if this potentially confounding effect exists. We recalculated Tables 2, 3, 4 and 5 for the subset of investors who answered 5, 6 or 7 to Question 7. The results display a similar pattern to those in Tables 2-5, and so we have not reproduced them here.

\section{Summary and conclusions}

In this paper we have tried to contribute to the solution of the dividend puzzle. Most of the finance theory on dividend policy starts with the behavior of shareholders. The empirical finance literature on this topic either studies share price reactions or surveys corporate executives for their opinions. No one has asked individual investors why they 
want to receive dividends. In this paper we have tried to fill this gap by submitting a questionnaire on cash and stock dividends to a Dutch consumer panel that is regularly surveyed on personal finance issues. We received 555 responses from consumers that have, or recently had, investments in stocks of individual companies or investment funds. We find that investors have a strong preference to receive dividends. If the company cannot pay cash dividends, they prefer to receive stock dividends compared to not receiving dividends at all. This clearly shows that they are definitely not neutral towards the dividend policy. We do not find much support for the "irrational" explanations of the existence of dividends, i.e. the uncertainty resolution theory of Gordon $(1961,1962)$ and the behavioral explanation of Shefrin and Statman (1984). We mostly find support for the latter in case of stock dividends. Furthermore, we find that investors partly want dividends because of transaction costs. The results are inconsistent with the agency theories of Easterbrook (1984) and Jensen (1986). On the other hand a strong support is found for the signaling theories of Bhattacharya (1979) and Miller and Rock (1985).

A useful continuation of this line of research would be a survey of institutional investors: pension funds, investment funds and financial institutions on their own account. They often face different tax rules than do individual investors, and their decision-making process is arguably better-informed. 


\section{Appendix: The Questionnaire}

This is the original English version, which we translated into Dutch for the panel.

\section{Question 1}

Do you currently own stocks of exchange-listed companies (other than investment funds)?

If the answer to this question is yes, please continue with Question 3. If the answer is no, please continue with Question 2.

\section{Question 2}

Did you own stocks of exchange-listed companies (other than investment funds) during the last three years?

\section{Question 3}

Do you currently own stocks of investment funds?

This question only refers to direct investments in investment funds. Indirect investments, such as investments in the context of an investment mortgage or a life annuity are excluded.

If the answer to this question is yes, please continue with Question 5. If the answer is no, please continue with Question 4.

\section{Question 4}

Did you own stocks of investment funds during the last three years?

This question only refers to direct investments in investment funds. Indirect investments, such as investments in the context of an investment mortgage or a life annuity are excluded.

\section{Remark 1 for the respondents:}

A. If you have answered yes to either Question 1 or 2 AND yes to either Question 3 or 4, then please continue with Question 5.

B. If you have answered no to both Questions 1 and 2 AND yes to either Question 3 or 4, please continue with Question 6.

C. If you did not fulfill conditions A and B, but you have answered yes to at least one of the questions from 1 to 4, then please continue with Question 7.

D. If you have answered no to all of the first four questions, then this questionnaire is finished for you.

Remark 2 for the respondents: Questions 5 to 26 have to be answered for cash dividends only. 


\section{Question 5}

Please indicate on the following scale whether you hold some shares in investment funds in addition to holding shares in individual companies directly, because investment funds pay more reliable dividends $(1=$ completely disagree; $4=$ neutral; $7=$ completely agree; 8 = no opinion/don’t know).

\section{Question 6}

Please indicate on the following scale whether you hold shares in investment funds only and no shares in individual companies, because investment funds pay more reliable dividends $(1=$ completely disagree; $4=$ neutral; $7=$ completely agree; $8=$ no opinion/don't know).

\section{Question 7}

Please indicate on the following scale whether you like your stocks to pay dividends or not $(1$ = I do not want dividends; 4 = neutral; 7 = I want dividends; 8 = no opinion/don't know).

\section{Question 8}

An individual investor can get money from shares either by receiving dividends or by selling some of the shares. Both ways require transaction costs. Transaction costs are the costs that the bank or the broker charges you when paying a dividend or selling a share of common stock. Please indicate on a scale from 1 to 7 your opinion on the following statement.

The transaction costs can be different between the sale of common stock and the receipt of a dividend. Because of this difference I have a preference for receiving dividends. ( 1 = no, definitely not; 4 = neutral; 7 = yes, definitely; 8 = no opinion/don’t know).

\section{Question 9}

Companies that pay little or no dividends have more cash flow left to invest in new growth projects than companies that pay a lot of their income in dividends. Comparing high dividend yield companies with low dividend yield companies, do you believe that the high dividend companies are $1=$ less risky; $4=$ just as risky; $7=$ more risky; $8=$ no opinion/don’t know.

\section{Question 10}

Please indicate your opinion on a scale from 1 to 7 on the following statement. Shares that pay relatively higher dividends are less risky. ( 1 = strongly disagree; 4 = neutral; 7 = strongly agree; 8 = no opinion/don’t know $)$.

\section{Question 11}


The total return on a share of stock consists of the capital gains and the dividend yield. The dividend yield is the dividend expressed as a percentage of the stock price. In a down market, the dividend yield is a more substantial fraction of the total returns than in an up market. Is this a reason for you to invest more in dividend paying shares in a down market?

(1 = no, definitely not; 4 = neutral; 7 = yes, definitely; 8 = no opinion/don’t know).

\section{Question 12}

Do you think that dividend-paying stocks offer more certainty about the companies' future earnings prospects compared to stocks that do not pay dividends? $(1=$ no, definitely not; 4 = neutral; 7 = yes, definitely; 8 = no opinion/don’t know).

\section{Question 13}

Do you buy dividend-paying stocks because these companies generate real earnings and are less likely to "cook the books" ( 1 = no definitely not; 4 = neutral; 7 = yes, definitely; $8=$ no opinion/don’t know).

\section{Question 14}

How much of the total dividends that you receive do you use for current consumption purposes? Consumption purposes are expenditures for the purchase of goods such as cars, washing machines, food and such or for services such as holidays, going out to dinner and such. It is emphasized that the purchase of stocks, bonds and deposits do not classify as consumption purposes.

( $\_-20 \%$ of the total amount; _ 20-40\% of the total amount; _ $40-60 \%$ of the total amount; $\quad 60-80 \%$ of the total amount; $-80-100 \%$ of the total amount; $8=$ no opinion/don't know).

\section{Question 15}

How much of the total income that you receive from regular salary (including pension) and social benefits do you use for consumption purposes? ( $\_-20 \%$ of the total amount; - $20-40 \%$ of the total amount; $-40-60 \%$ of the total amount; $-60-80 \%$ of the total amount; _ 80-100\% of the total amount; _ I receive no income from these sources; _ no opinion/don't know).

\section{Question 16}

Would you for consumption purposes sell part of your stocks in a company that has always paid a dividend, if the management of that company would decide not to pay a dividend anymore? $(1=$ no, definitely not; $4=$ neutral; $7=$ yes, definitely; $8=$ no opinion/don’t know). 


\section{Question 17}

In economic downturns, fewer good investment projects are available. Would you, for this reason, invest more in dividend paying stocks in down markets or in economic downturns? $(1=$ no, definitely not; $4=$ neutral; 7 = yes, definitely; $8=$ no opinion/don't know).

\section{Question 18}

Do you wish to receive dividends because you believe the company will otherwise invest the money unprofitably? ( $1=$ no, definitely not; $4=$ neutral; $7=$ yes, definitely; $8=$ no opinion/don’t know).

\section{Question 19}

Would you like to receive cash dividends if a company would have to issue new shares of common stock in order to be able to afford the dividend payment? $(1=$ no, definitely not; 4 = neutral; 7 = yes, definitely; 8 = no opinion/don't know).

\section{Question 20}

Would you like to receive cash dividends if a company would have to borrow money in order to be able to afford the dividend payment? $(1=$ no, definitely not; $4=$ neutral; $7=$ yes, definitely; 8 = no opinion/don’t know).

\section{Question 21}

Do you think that a dividend increase tells you something about the company's future performance? A dividend increase is an indication that the future performance: ( 1 = will deteriorate strongly; 7 = will improve strongly; 8 = no opinion/don't know) Please choose 4 if a dividend increase does not tell you anything on the future performance of the company.

\section{Question 22}

Do you think that a dividend decrease tells you something about the company's future performance? A dividend decrease is an indication that the future performance: ( 1 = will deteriorate strongly; 7 = will improve strongly; 8 = no opinion/don't know)

Please choose 4 if a dividend decrease does not tell you anything on the future performance of the company.

\section{Question 23}

Suppose a company would stop paying dividends and instead use the money to buy back its own stocks on the market. How would you value such a decision? ( 1 = extremely negative; 4 = neutral; 7 = extremely positive; 8 = no opinion/don’t know). 


\section{Question 24}

Do you think that a stock repurchase is good because it is a signal that the stock is undervalued? (1 = no, definitely not; $4=$ neutral; $7=$ yes, definitely; $8=$ no opinion/don't know).

\section{Question 25}

Please indicate on the following scale whether you like your stocks to pay dividends or not for tax reasons. $(1=$ no, definitely not; $7=$ yes, definitely; $8=$ no opinion $/$ don't know). Please choose 4 if, for tax reasons, you are neutral towards dividends. Note: please answer this question in light of the current tax system (IB 2001).

\section{Question 26}

Please indicate on the following scale whether you used to like stocks to pay dividends or not for tax reasons under the old income tax regime (prevailing before January 1, 2001). $(1=$ no, definitely not; 7 = yes, definitely; $8=$ no opinion/don't know $)$. Please choose 4 if, for tax reasons, you were neutral towards dividends before January 1, 2001.

\section{Question 27}

Did you submit an income tax form for the year 2001 in order to ask for a reimbursement of the dividend surtax ("dividendbelasting”)? (1 = yes; 2 = no).

Remark 3 for the respondents: Questions 28 to 32 go into the comparison of cash and stock dividends. A cash dividend is a dividend in the form of cash. A stock dividend is a dividend in the form of shares of common stock.

\section{Question 28}

Please indicate on a scale from 1 to 7 whether you think that stock dividends are like cash dividends or whether they are like (small) stock splits.

In a stock split a company decides to exchange each share of common stock in a fixed number of new shares.

Stock dividends:

( 1 = more look like cash dividends; 7 = more look like stock splits; $8=$ no opinion/don't know). Please answer "4" if you think that they are neither like cash dividends nor like stock splits.

\section{Question 29}

Transaction costs are the costs that the bank or broker charges you when paying a dividend or selling shares.

Can you please give your opinion on a scale from 1 to 7 on the following statement? 
Because of transaction costs I have a preference for stock dividends over cash dividends. (1 = No, definitely not; 7 = Yes, definitely; 8 = no opinion/don’t know).

Please answer "4" if transaction costs do not play a role for you in the choice between stock and cash dividends.

\section{Question 30}

If you only consider income taxes, do you currently have a preference for stock or for cash dividends? Please answer this question in the context of the currently prevailing tax system that is operational since January 1, 2001

(1 = I prefer cash dividends; 7 = I prefer stock dividends; 8 = no opinion/don't know). Please answer " 4 " if income taxes do not play a role for you in the choice between stock and cash dividends.

\section{Question 31}

If you only consider income taxes, did you use to have a preference for stock or for cash dividends under the old tax regime (prevailing before January 1, 2001)? (1 = I used to prefer cash dividends; $4=$ neutral; $7=$ I used to prefer stock dividends; $8=$ no opinion/don't know). Please answer " 4 ” if income taxes did not play a role for you before January 1, 2001 in the choice between stock and cash dividends.

\section{Question 32}

Suppose a company does not have enough cash to pay a dividend. What is your preference in such a case: (1) to receive a stock dividend or (2) not to receive a dividend at all? $(1=$ preference not to receive a stock dividend; $4=$ neutral; $7=$ preference to receive a stock dividend; $8=$ no opinion/don't know). 


\section{References}

Allen, F., Michaely, R., 2004, Payout policy, in: G. Constantinides, M. Harris, and R. Stulz, North-Holland handbook of economics (North-Holland, Amsterdam (in press)).

Baker, H.K., Farrelly, G.E., Edelman, R.B., 1985, A survey of management views on dividend policy, Financial Management 14, 78-83.

Baker, H.K., Powell, G.E., Veit, T.T., 2002, Revisiting managerial perspectives on dividend policy, Journal of Economics and Finance 26, 267-283.

Baker, M.,. Wurgler, J., 2003, Why are dividends disappearing? An empirical analysis, Working Paper, Harvard Business School.

Barberis, N., Thaler, R., 2004, A survey of behavioral finance, in: G. Constantinides, M. Harris, and R. Stulz, North-Holland handbook of economics, North-Holland, Amsterdam (in press).

Bhattacharya, S., 1979, Imperfect information, dividend policy and the "bird in the hand" fallacy, Bell Journal of Economics 10, 259-270.

Black, F., 1976, The dividend puzzle, The Journal of Portfolio Management 2, 5-8.

Black, F., Scholes, M., 1974, The effects of dividend yield and dividend policy on common stock prices and returns, Journal of Financial Economics 1, 1-22.

Brav, A., Graham, J.R., Harvey, C.R., Michaely, R., 2004, Payout policy in the $21^{\text {st }}$ century, Journal of Financial Economics (in press).

Brealey, R.A., Myers, S.C., 2003, Principles of Corporate Finance ( $7^{\text {th }}$ edition, McGrawHill, New York).

Brennan, M.J., 1970, Taxes, market valuation and financial policy, National Tax Journal 23, 417-429.

Comment, R., Jarrell, G.A., 1991, The relative signaling power of Dutch-auction and fixed-price self-tender offers and open market share repurchases, The Journal of Finance 46, 1243-1271.

DeBondt, W.F.M., Thaler, R.H., 1995, Financial decision making in markets and firms: A behavioral perspective, in: R. Jarrow, V. Maksimovic, and W.T. Ziemba, Finance, Handbooks in operations research and management science, vol. 9 (North-Holland, Amsterdam, 385-410). 
De Jong, A., DeJong, D., Mertens, G., Wasley, C., 2004, The role of self-regulation in corporate governance: evidence and implications from The Netherlands, Journal of Corporate Finance (in press).

De Jong, A., Dijk, R.V., Veld, C., 2003, The dividend and share repurchase policies of Canadian firms: empirical evidence based on an alternative research design, International Review of Financial Analysis, 12, 349-377.

De Jong, A., Kabir, R., Marra, T., Röell, A., 2001, Ownership and control in the Netherlands, in: F. Barca, and M. Becht, The Control of Corporate Europe, Oxford University Press, Oxford (United Kingdom).

Donkers, B., van Soest, A., 1999, Subjective measures of household preferences and financial decisions, Journal of Economic Psychology 20, 613-642.

Donkers, B., Melenberg, B., van Soest, A., 2001, Estimating risk attitudes using lotteries - a large sample approach, Journal of Risk and Uncertainty 22, 165-195.

Dorsman, A., 1988, Dividend en dividendpolitiek (transl. Dividend and dividend policy), Stenfert Kroese BV, Leiden (the Netherlands).

Easterbrook, F.H., 1984, Two agency-cost explanations of dividends, American Economic Review 74, 650-659.

Fama, E.F., French, K.R., 2001, Disappearing dividends: changing firm characteristics or lower propensity to pay? Journal of Financial Economics 60, 3-43.

Frankfurter, G.M., Wood, B.G., 2002, Dividend policy theories and their empirical tests, International Review of Financial Analysis 11, 111-138.

Fuller, K., Goldstein, M., 2003, Dividend policy and market movements, Working Paper, Terry College of Business, University of Georgia.

Glaser, B.G., Strauss, A.C., 1967, The discovery of grounded theory: strategies for qualitative research, Aldine Press, Chicago.

Goergen, M., Renneboog, L., Correia da Silva, L., 2004, When do German firms change their dividends? Journal of Corporate Finance (in press).

Gordon, M., 1961, The Investment, Financing, and Valuation of the Corporation, Richard D. Irwin, Homewood (Illinois).

Gordon, M., 1962, The savings, investment and valuation of a corporation, Review of Economics and Statistics 44, 37-51. 
Graham, J.R., Harvey, C.R., 2001, The theory and practice of corporate finance: evidence from the field, Journal of Financial Economics 60, 187-243.

Grullon, G., Michaely, R., 2002, Dividends, share repurchases, and the substitution hypothesis, The Journal of Finance 57, 1649-1684.

Gugler, K., 2003, Corporate governance, dividend payout policy, and the interrelation between dividends, and capital investment, Journal of Banking and Finance 27, 12971321.

Gugler, K., Yurtoglu, B.B., 2003, Corporate governance and dividend pay-out policy in Germany, European Economic Review 47, 731-758.

Ikenberry, D., Lakonishok, J., Vermaelen, T., 1995, Market underreaction to open market share repurchases, Journal of Financial Economics 39, 181-208.

Ikenberry, D., Lakonishok, J., Vermaelen, T., 2000, Stock repurchases in Canada: performance and strategic trading, Journal of Finance 55, 2373-2398.

Jagannathan, M., Stephens, C.P., Weisbach, M.S., 2000, Financial flexibility and the choice between dividends and stock repurchases, Journal of Financial Economics 57, 355-384.

Jensen, M.C., 1986, Agency costs of free cash flow, corporate finance and takeovers, American Economic Review 76, 323-329.

Lease, R.C., Kose, J., Kalay, A., Loewenstein, U., Sarig, O.H., 2000, Dividend policy: Its impact on firm value (Harvard Business School Press).

Lease, R.C., Lewellen, W., Schlarbaum, G., 1976, Market segmentation: evidence on the individual investor, Financial Analysts Journal 32, 53-60 (September-October).

Litzenberger, R.H., Ramaswamy, K., 1982, The effects of dividends on common stock prices: tax effects or information effects, The Journal of Finance 37, 429-443.

Lintner, J., 1956, Distribution of incomes of corporations among dividends, retained earnings, and taxes, American Economic Review 46, 97-113.

Meussen, G.T.K., 2000, Netherlands: Income tax act 2001, European Taxation 40, 490498.

Miller, M., Rock, K., 1985, Dividend policy under asymmetric information, The Journal of Finance 40, 1031-1051.

Miller, M., Modigliani, F., 1961, Dividend policy, growth and the valuation of shares, Journal of Business 34, 411-433. 
Myers, S.C., Majluf, N.S., 1984, Corporate financing and investment decisions when firms have information that investors do not have, Journal of Financial Economics 13, 187-221.

Ross, S.A., Westerfield, R.W., Jaffe, J.E., 2002, Corporate Finance, (McGraw-Hill, New York).

Shefrin, H.M., Statman, M., 1984, Explaining investor preference for cash dividends, Journal of Financial Economics 13, 253-282.

Shefrin, H.M., Thaler, R., 1988, The behavioral life-cycle hypothesis, Economic Inquiry 26, 609-643.

Winnett, A., Lewis, A., 1995, Household accounts, mental accounts, and savings behaviour: some old economics rediscovered? Journal of Economic Psychology 16, 431-448. 

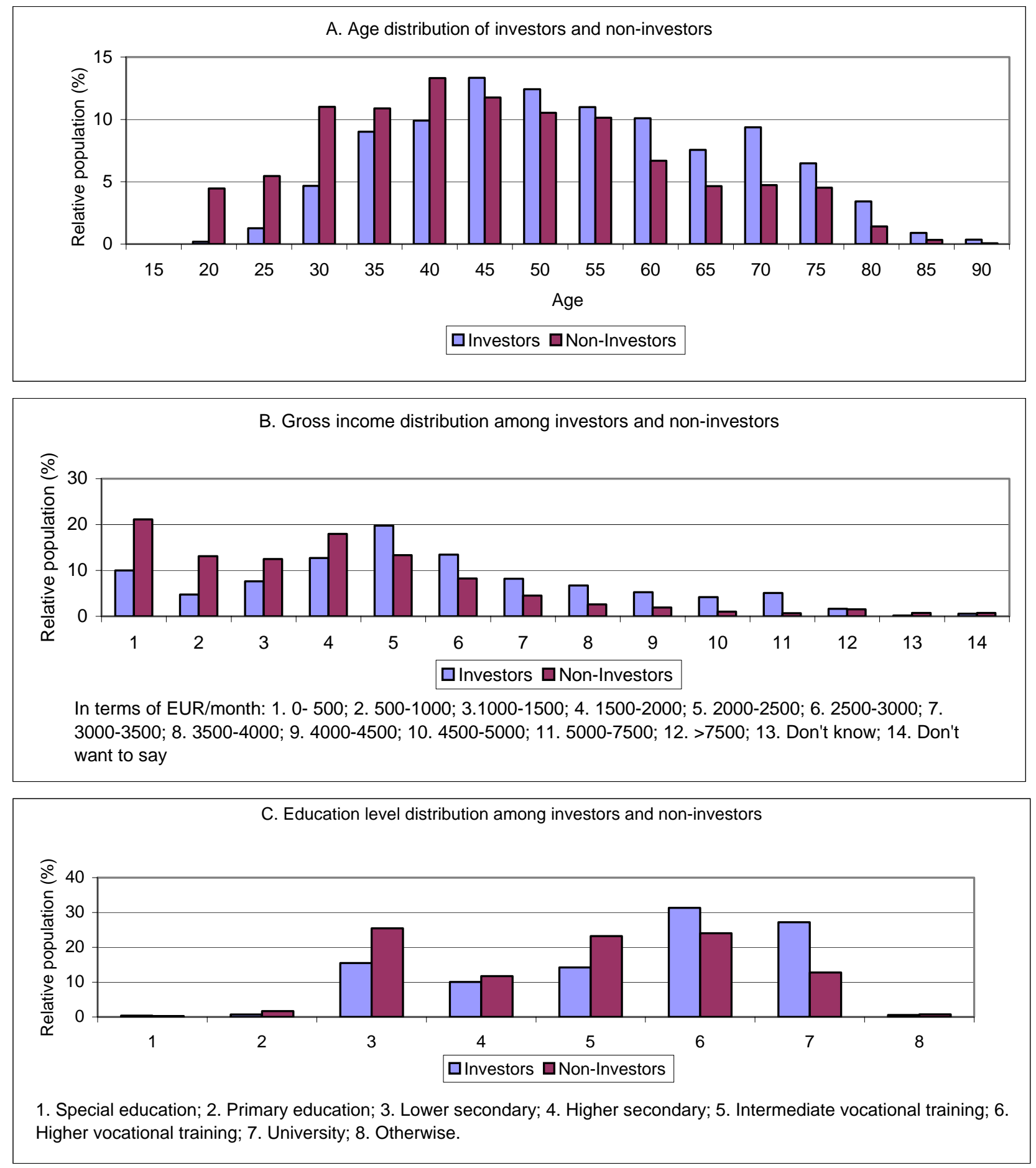

Fig. 1. Demographic distributions of survey respondents. Among survey respondents, there are 555 investors who own stocks and/or investment funds, and there are 1,480 non-investors who do not own stocks or investment funds. This figure shows the age, income and education distributions of investors and non-investors. 
Table 1

Summary demographic statistics of survey respondents

\begin{tabular}{|c|c|}
\hline Number of CentER members surveyed & 2,723 \\
\hline Number of responses & 2,035 (74.7\% response rate) \\
\hline $\begin{array}{l}\text { Number of respondents who are investors (who own stocks or investment funds) and } \\
\text { who have answered most survey questions }\end{array}$ & 555 (27.3\% of respondents) \\
\hline \multicolumn{2}{|l|}{ Number of investors who: } \\
\hline own both stocks and investment funds & 236 (42.5\% of investors) \\
\hline own stocks only & $103(18.6 \%)$ \\
\hline own investment funds only & 216 (38.9\%) \\
\hline are younger than 55 & $333(60.0 \%)$ \\
\hline are 55 or older & $222(40.0 \%)$ \\
\hline earn a high income (monthly gross income $\geq 3,000$ EUR) & 175 (31.5\%) \\
\hline earn a low income (monthly gross income <3,000 EUR) & 380 (68.5\%) \\
\hline have university education & $151(27.2 \%)$ \\
\hline have no university education & $404(72.8 \%)$ \\
\hline
\end{tabular}

A sample of 2,723 CentER members (in the Netherlands) was selected for the survey. This table reports the summary demographic statistics of survey respondents. The survey results shown in the subsequent tables are from the 555 investors only. 
Table 2

Responses to questions on cash dividends

Abbreviated question description

Statistics

All
investors

$\begin{array}{cccc}\text { Owning } & \text { Owning } & \text { Age below Age above } \\ \text { stocks } & \text { funds (and } & 55 & 55\end{array}$

High Low

University No

only

income

educated university

stocks) education

Theory a. MM dividend irrelevance theorem

\begin{tabular}{|c|c|c|c|c|c|c|c|c|c|c|}
\hline \multirow{7}{*}{$\begin{array}{l}\text { 7. Do you like your stocks to pay } \\
\text { dividends? ( } 1 \text { = I do not want dividends; } 4 \\
=\text { neutral; } 7 \text { = I want dividends) }\end{array}$} & Mean & $4.98 \bullet$ & 5.20 & 4.93 & $4.84^{* *}$ & $5.19 * *$ & 4.86 & 5.04 & 4.87 & 5.03 \\
\hline & $t$-stat & 14.04 & 6.91 & 12.25 & 8.91 & 11.63 & 6.63 & 12.56 & 6.44 & 12.54 \\
\hline & Median & $5 \cdots$ & 5 & 5 & $5 * *$ & $5^{* *}$ & 5 & 5 & 5 & 5 \\
\hline & Binomial $p$ & 0.0000 & 0.0000 & 0.0000 & 0.0000 & 0.0000 & 0.0000 & 0.0000 & 0.0000 & 0.0000 \\
\hline & $\%(>4)$ & 60.5 & 62.9 & 60.0 & 57.3 & 65.1 & 58.4 & 61.5 & 55.6 & 62.4 \\
\hline & $\%(<4)$ & 12.3 & 9.3 & 13.0 & 13.7 & 10.4 & 15.7 & 10.8 & 11.8 & 12.5 \\
\hline & $N$ & 519 & 97 & 422 & 307 & 212 & 166 & 353 & 144 & 375 \\
\hline \multicolumn{11}{|c|}{ Theory $b$. Transaction costs } \\
\hline \multirow{7}{*}{$\begin{array}{l}\text { 8. I have a preference for receiving } \\
\text { dividends because of transaction costs. }(1= \\
\text { no, definitely not; } 4=\text { neutral; } 7=\text { yes, } \\
\text { definitely) }\end{array}$} & Mean & $4.20^{\bullet \bullet}$ & $4.71 * * *$ & $4.08 * * *$ & $4.09 *$ & $4.35 *$ & $4.01 *$ & $4.29 *$ & $4.00 *$ & $4.28 *$ \\
\hline & $t$-stat & 2.79 & 4.33 & 0.95 & 0.99 & 3.15 & 0.10 & 3.49 & 0.00 & 3.31 \\
\hline & Median & $4 \bullet \bullet$ & $4 * * *$ & $4 * * *$ & 4 & 4 & $4 * *$ & $4 * *$ & $4 * *$ & $4 * *$ \\
\hline & Binomial $p$ & 0.0002 & 0.0000 & 0.0535 & 0.0251 & 0.0029 & 0.8199 & 0.0000 & 0.9007 & 0.0000 \\
\hline & $\%(>4)$ & 33.3 & 45.7 & 30.2 & 32.3 & 34.5 & 26.8 & 36.3 & 25.0 & 36.6 \\
\hline & $\%(<4)$ & 20.5 & 12.0 & 22.6 & 21.9 & 18.6 & 24.8 & 18.5 & 23.5 & 19.3 \\
\hline & $N$ & 463 & 92 & 371 & 269 & 194 & 149 & 314 & 132 & 331 \\
\hline \multicolumn{11}{|c|}{ Theory c. Uncertainty resolution (Bird-in-the-hand) } \\
\hline \multirow{7}{*}{$\begin{array}{l}\text { 9. Comparing high dividend yield } \\
\text { companies with low dividend yield } \\
\text { companies, do you believe that the high } \\
\text { dividend companies are: } 1 \text { = less risky; } 4= \\
\text { just as risky; } 7 \text { = more risky) }\end{array}$} & Mean & $4.13^{\bullet}$ & 3.99 & 4.17 & $4.04^{* *}$ & $4.26^{* *}$ & $3.91 * * *$ & $4.25 * * *$ & 4.15 & 4.13 \\
\hline & $t$-stat & 2.37 & -0.09 & 2.76 & 0.53 & 3.28 & -0.89 & 3.54 & 1.35 & 1.95 \\
\hline & Median & $4 \bullet$ & $4^{*}$ & $4 *$ & $4^{*}$ & $4^{*}$ & $4 * * *$ & $4^{* * *}$ & 4 & 4 \\
\hline & Binomial $p$ & 0.0083 & 0.8714 & 0.0018 & 0.4478 & 0.0018 & 0.4188 & 0.0002 & 0.1608 & 0.0317 \\
\hline & $\%(>4)$ & 26.8 & 22.5 & 27.8 & 24.7 & 29.7 & 17.0 & 31.8 & 26.7 & 26.8 \\
\hline & $\%(<4)$ & 17.9 & 25.0 & 16.3 & 21.0 & 13.7 & 22.0 & 15.9 & 17.2 & 18.2 \\
\hline & $N$ & 418 & 80 & 338 & 243 & 175 & 141 & 277 & 116 & 302 \\
\hline
\end{tabular}




\begin{tabular}{|c|c|c|c|c|c|c|c|c|c|c|}
\hline \multirow[t]{2}{*}{ Abbreviated question description } & \multirow[t]{2}{*}{ Statistics } & \multirow{2}{*}{$\begin{array}{c}\text { All } \\
\text { investors }\end{array}$} & \multirow{2}{*}{$\begin{array}{l}\text { Owning } \\
\text { stocks } \\
\text { only }\end{array}$} & \multirow{2}{*}{$\begin{array}{l}\text { Owning } \\
\text { funds (and } \\
\text { perhaps } \\
\text { stocks) }\end{array}$} & \multicolumn{2}{|c|}{ Age below Age above } & \multirow{2}{*}{$\begin{array}{c}\text { High } \\
\text { income }\end{array}$} & \multirow{2}{*}{$\begin{array}{c}\text { Low } \\
\text { income }\end{array}$} & \multirow{2}{*}{$\begin{array}{l}\text { University } \\
\text { educated }\end{array}$} & \multirow{2}{*}{$\begin{array}{l}\text { No } \\
\text { university } \\
\text { education }\end{array}$} \\
\hline & & & & & 55 & 55 & & & & \\
\hline \multirow{7}{*}{$\begin{array}{l}\text { 10. Shares that pay relatively higher } \\
\text { dividends are less risky. }(1=\text { strongly } \\
\text { disagree; } 4=\text { neutral; } 7=\text { strongly agree })\end{array}$} & Mean & $3.62^{\bullet \bullet}$ & 3.83 & 3.58 & 3.66 & 3.57 & 3.62 & 3.63 & 3.57 & 3.65 \\
\hline & $t$-stat & -5.99 & -1.12 & -6.14 & -4.03 & -4.50 & -3.36 & -4.97 & -3.39 & -4.93 \\
\hline & Median & $4 \bullet \bullet$ & 4 & 4 & 4 & 4 & 4 & 4 & 4 & 4 \\
\hline & Binomial $p$ & 0.0000 & 0.2026 & 0.0000 & 0.0001 & 0.0000 & 0.0022 & 0.0000 & 0.0067 & 0.0000 \\
\hline & $\%(>4)$ & 21.0 & 24.7 & 20.2 & 23.1 & 18.2 & 23.4 & 19.8 & 24.4 & 19.8 \\
\hline & $\%(<4)$ & 43.2 & 37.0 & 44.5 & 43.5 & 42.7 & 44.2 & 42.7 & 45.5 & 42.3 \\
\hline & $N$ & 447 & 81 & 366 & 255 & 192 & 154 & 293 & 123 & 324 \\
\hline \multirow{7}{*}{$\begin{array}{l}\text { 11. In a down market, the dividend yield is } \\
\text { a more substantial fraction of the total } \\
\text { returns than in an up market. Is this a } \\
\text { reason for you to invest more in dividend } \\
\text { paying shares in a down market? ( } 1=\text { no, } \\
\text { definitely not; } 4=\text { neutral; } 7=\text { yes, } \\
\text { definitely) }\end{array}$} & Mean & $3.46 \bullet \bullet$ & 3.34 & 3.49 & $3.26 * * *$ & $3.72 * * *$ & 3.53 & 3.43 & 3.57 & 3.42 \\
\hline & $t$-stat & -6.92 & -3.85 & -5.84 & -6.93 & -2.47 & -3.27 & -6.26 & -2.73 & -6.53 \\
\hline & Median & $4 \bullet$ & 4 & 4 & $4 * * *$ & $4 * * *$ & 4 & 4 & 4 & 4 \\
\hline & Binomial $p$ & 0.0000 & 0.0044 & 0.0005 & 0.0000 & 0.1915 & 0.0617 & 0.0000 & 0.0662 & 0.0001 \\
\hline & $\%(>4)$ & 24.3 & 22.4 & 24.8 & 23.0 & 26.0 & 30.5 & 21.1 & 26.6 & 23.4 \\
\hline & $\%(<4)$ & 41.5 & 49.4 & 39.7 & 47.3 & 33.9 & 44.2 & 40.1 & 40.6 & 41.9 \\
\hline & $N$ & 448 & 85 & 363 & 256 & 192 & 154 & 294 & 128 & 320 \\
\hline \multicolumn{11}{|c|}{ Theory d. A smaller influence from accounting manipulations } \\
\hline \multirow{7}{*}{$\begin{array}{l}\text { 12. Do you think that dividend-paying } \\
\text { stocks offer more certainty about the } \\
\text { companies' future earnings prospects } \\
\text { compared with stocks that do not pay } \\
\text { dividends? ( } 1 \text { = no, definitely not; } 4= \\
\text { neutral; } 7=\text { yes, definitely) }\end{array}$} & Mean & 3.92 & 4.00 & 3.91 & $3.73 * * *$ & $4.19 * * *$ & 3.90 & 3.94 & 3.97 & 3.91 \\
\hline & $t$-stat & -1.09 & 0.00 & -1.26 & -2.95 & 1.82 & -0.83 & -0.74 & -0.23 & -1.16 \\
\hline & Median & 4 & 4 & 4 & $4 * * *$ & $4 * * *$ & 4 & 4 & 4 & 4 \\
\hline & Binomial $p$ & 0.4255 & 0.4270 & 0.6782 & 0.1205 & 0.0020 & 0.8392 & 0.4419 & 0.6530 & 0.5587 \\
\hline & $\%(>4)$ & 32.1 & 37.6 & 30.8 & 25.5 & 41.4 & 33.1 & 31.6 & 35.0 & 31.0 \\
\hline & $\%(<4)$ & 28.9 & 29.4 & 28.8 & 33.3 & 22.7 & 31.1 & 27.7 & 30.8 & 28.2 \\
\hline & $N$ & 436 & 85 & 351 & 255 & 181 & 151 & 285 & 120 & 316 \\
\hline \multirow{7}{*}{$\begin{array}{l}\text { 13. Do you buy dividend-paying stocks } \\
\text { because these companies generate real } \\
\text { earnings and are less likely to "cook the } \\
\text { books"? ( } 1 \text { = no definitely not; } 4 \text { = neutral; } \\
7 \text { = yes, definitely) }\end{array}$} & Mean & $3.66^{\bullet \bullet}$ & 3.57 & 3.68 & $3.44 * * *$ & $3.97 * * *$ & $3.46^{*}$ & $3.76^{*}$ & 3.54 & 3.70 \\
\hline & $t$-stat & -4.57 & -2.42 & -3.90 & -5.57 & -0.30 & -3.97 & -2.67 & -3.11 & -3.40 \\
\hline & Median & $4^{\star}$ & 4 & 4 & $4 * * *$ & $4 * * *$ & $4 *$ & $4 *$ & 4 & 4 \\
\hline & Binomial $p$ & 0.0517 & 0.2717 & 0.1191 & 0.0005 & 0.2898 & 0.0279 & 0.5285 & 0.1133 & 0.2342 \\
\hline & $\%(>4)$ & 26.4 & 26.2 & 26.4 & 22.3 & 32.3 & 27.2 & 25.9 & 27.8 & 25.8 \\
\hline & $\%(<4)$ & 33.7 & 36.9 & 33.0 & 39.2 & 25.8 & 42.4 & 29.0 & 39.8 & 31.1 \\
\hline & $N$ & 451 & 84 & 367 & 265 & 186 & 158 & 293 & 133 & 318 \\
\hline
\end{tabular}




\begin{tabular}{|c|c|c|c|c|c|c|c|c|c|c|}
\hline Abbreviated question description & Statistics & $\begin{array}{c}\text { All } \\
\text { investors }\end{array}$ & $\begin{array}{c}\text { Owning } \\
\text { stocks } \\
\text { only }\end{array}$ & $\begin{array}{c}\text { Owning } \\
\text { funds (and } \\
\text { perhaps } \\
\text { stocks) }\end{array}$ & $\begin{array}{c}\text { Age below } \\
55\end{array}$ & $\begin{array}{l}\text { Age above } \\
55\end{array}$ & \multirow[t]{2}{*}{$\begin{array}{c}\text { High } \\
\text { income }\end{array}$} & \multirow[t]{2}{*}{$\begin{array}{c}\text { Low } \\
\text { income }\end{array}$} & \multirow[t]{2}{*}{$\begin{array}{l}\text { University } \\
\text { educated }\end{array}$} & \multirow[t]{2}{*}{$\begin{array}{l}\text { No } \\
\text { university } \\
\text { education }\end{array}$} \\
\hline \multicolumn{7}{|c|}{ Theory f. Free cash flow } & & & & \\
\hline \multirow{7}{*}{$\begin{array}{l}\text { 17. In economic downturns, fewer good } \\
\text { investment projects are available. Would } \\
\text { you, for this reason, invest more in } \\
\text { dividend paying stocks in down markets or } \\
\text { in economic downturns? ( } 1 \text { = no, definitely } \\
\text { not; } 4 \text { = neutral; } 7=\text { yes, definitely) }\end{array}$} & Mean & $3.54^{\bullet \bullet}$ & 3.49 & 3.56 & 3.46 & 3.65 & 3.70 & 3.46 & 3.70 & 3.48 \\
\hline & t-stat & -6.17 & -3.11 & -5.35 & -5.73 & -2.94 & -2.38 & -5.88 & -2.04 & -6.01 \\
\hline & Median & $4 \bullet \bullet$ & 4 & 4 & 4 & 4 & 4 & 4 & 4 & 4 \\
\hline & Binomial $p$ & 0.0000 & 0.0127 & 0.0008 & 0.0002 & 0.0469 & 0.4168 & 0.0000 & 0.4096 & 0.0000 \\
\hline & $\%(>4)$ & 22.1 & 19.8 & 22.7 & 19.3 & 25.8 & 29.1 & 18.5 & 26.2 & 20.6 \\
\hline & $\%(<4)$ & 37.5 & 41.9 & 36.5 & 37.4 & 37.6 & 35.1 & 38.7 & 32.8 & 39.3 \\
\hline & $N$ & 448 & 86 & 362 & 254 & 194 & 151 & 297 & 122 & 326 \\
\hline \multirow{7}{*}{$\begin{array}{l}\text { 18. Do you wish to receive dividends } \\
\text { because you believe the company will } \\
\text { otherwise invest the money unprofitably? } \\
\text { ( } 1 \text { = no, definitely not; } 4 \text { = neutral; } 7=\text { yes, } \\
\text { definitely) }\end{array}$} & Mean & $3.06 \bullet \bullet$ & 2.93 & 3.10 & $2.81 * * *$ & $3.41 * * *$ & $2.88^{*}$ & $3.15^{*}$ & $2.75^{* * *}$ & $3.19 * * *$ \\
\hline & $t$-stat & -13.15 & -6.28 & -11.55 & -12.85 & -5.53 & -8.99 & -9.77 & -10.20 & -9.43 \\
\hline & Median & $3^{\bullet \bullet}$ & 3 & 3.5 & $3 * * *$ & $4 * * *$ & $3^{*}$ & $4^{*}$ & $3^{* *}$ & $4^{* *}$ \\
\hline & Binomial $p$ & 0.0000 & 0.0000 & 0.0000 & 0.0000 & 0.0000 & 0.0000 & 0.0000 & 0.0000 & 0.0000 \\
\hline & $\%(>4)$ & 13.0 & 15.4 & 12.4 & 9.2 & 18.2 & 11.5 & 13.7 & 6.7 & 15.5 \\
\hline & $\%(<4)$ & 51.0 & 54.9 & 50.0 & 58.3 & 40.9 & 56.4 & 48.2 & 59.7 & 47.5 \\
\hline & $N$ & 469 & 91 & 378 & 271 & 198 & 156 & 313 & 134 & 335 \\
\hline \multicolumn{11}{|c|}{ Theory g. Agency costs } \\
\hline \multirow{7}{*}{$\begin{array}{l}\text { 19. Would you like to receive cash } \\
\text { dividends if a company would have to issue } \\
\text { new shares of common stock in order to be } \\
\text { able to afford the dividend payment? }(1= \\
\text { no, definitely not; } 4=\text { neutral; } 7=\text { yes, } \\
\text { definitely) }\end{array}$} & Mean & $2.40^{\bullet \bullet}$ & 2.54 & 2.37 & 2.43 & 2.36 & $2.19 * *$ & $2.51^{* *}$ & 2.32 & 2.44 \\
\hline & $t$-stat & -23.66 & -8.98 & -21.98 & -17.41 & -16.01 & -15.76 & -17.93 & -13.44 & -19.47 \\
\hline & Median & $2 \bullet \bullet$ & 2 & 2 & 2 & 2 & $2 * * *$ & $2 * * *$ & 2 & 2 \\
\hline & Binomial $p$ & 0.0000 & 0.0000 & 0.0000 & 0.0000 & 0.0000 & 0.0000 & 0.0000 & 0.0000 & 0.0000 \\
\hline & $\%(>4)$ & 7.4 & 8.9 & 7.1 & 7.5 & 7.4 & 5.0 & 8.7 & 6.5 & 7.8 \\
\hline & $\%(<4)$ & 73.7 & 70.0 & 74.5 & 71.6 & 76.4 & 78.3 & 71.3 & 73.9 & 73.6 \\
\hline & $N$ & 471 & 90 & 381 & 268 & 203 & 161 & 310 & 138 & 333 \\
\hline \multirow{7}{*}{$\begin{array}{l}20 \text {. Would you like to receive cash } \\
\text { dividends if a company would have to } \\
\text { borrow money in order to be able to afford } \\
\text { the dividend payment? ( } 1 \text { = no, definitely } \\
\text { not; } 4 \text { = neutral; } 7 \text { = yes, definitely) }\end{array}$} & Mean & $2.03 \bullet \bullet$ & 2.15 & 2.01 & 2.02 & 2.05 & 1.97 & 2.07 & 2.05 & 2.03 \\
\hline & t-stat & -32.31 & -11.96 & -30.28 & -25.58 & -19.92 & -19.55 & -25.74 & -17.48 & -27.15 \\
\hline & Median & $2 \bullet$ & 2 & 1 & 2 & 1 & 1 & 2 & 2 & 1 \\
\hline & Binomial $p$ & 0.0000 & 0.0000 & 0.0000 & 0.0000 & 0.0000 & 0.0000 & 0.0000 & 0.0000 & 0.0000 \\
\hline & $\%(>4)$ & 4.5 & 6.5 & 4.1 & 3.2 & 6.3 & 3.1 & 5.3 & 3.6 & 4.9 \\
\hline & $\%(<4)$ & 80.9 & 78.3 & 81.5 & 81.0 & 80.7 & 82.2 & 80.2 & 81.3 & 80.7 \\
\hline & $N$ & 486 & 92 & 394 & 279 & 207 & 163 & 323 & 139 & 347 \\
\hline
\end{tabular}




\begin{tabular}{|c|c|c|c|c|c|c|c|c|c|c|}
\hline Abbreviated question description & Statistics & $\begin{array}{c}\text { All } \\
\text { investors }\end{array}$ & $\begin{array}{c}\text { Owning } \\
\text { stocks } \\
\text { only }\end{array}$ & $\begin{array}{c}\text { Owning } \\
\text { funds (and } \\
\text { perhaps } \\
\text { stocks) }\end{array}$ & $\begin{array}{c}\text { Age below } \\
55\end{array}$ & $\begin{array}{l}\text { Age above } \\
55\end{array}$ & \multirow[t]{2}{*}{$\begin{array}{c}\text { High } \\
\text { income }\end{array}$} & \multirow[t]{2}{*}{$\begin{array}{c}\text { Low } \\
\text { income }\end{array}$} & $\begin{array}{l}\text { University } \\
\text { educated }\end{array}$ & \multirow[t]{2}{*}{$\begin{array}{c}\text { No } \\
\text { university } \\
\text { education }\end{array}$} \\
\hline \multicolumn{8}{|c|}{ Theory h. Signaling } & & & \\
\hline \multirow{7}{*}{$\begin{array}{l}\text { 21. Do you think that a dividend increase } \\
\text { tells you something about the company's } \\
\text { future performance? A dividend increase is } \\
\text { an indication that the future performance: } \\
\text { ( } 1 \text { = will deteriorate strongly; } 7 \text { = will } \\
\text { improve strongly) }\end{array}$} & Mean & $4.67^{\bullet \bullet+}$ & 4.77 & 4.64 & 4.61 & 4.75 & 4.62 & 4.69 & 4.68 & 4.66 \\
\hline & $t$-stat & 15.26 & 7.39 & 13.37 & 10.88 & 10.77 & 9.19 & 12.27 & 10.44 & 11.89 \\
\hline & Median & $5 \bullet \bullet$ & 5 & 4 & $4^{* *}$ & $5 * *$ & 4 & 5 & 5 & 4.5 \\
\hline & Binomial $p$ & 0.0000 & 0.0000 & 0.0000 & 0.0000 & 0.0000 & 0.0000 & 0.0000 & 0.0000 & 0.0000 \\
\hline & $\%(>4)$ & 50.7 & 56.7 & 49.4 & 46.8 & 56.3 & 47.8 & 52.2 & 52.5 & 50.0 \\
\hline & $\%(<4)$ & 3.8 & 3.3 & 3.9 & 4.0 & 3.6 & 2.5 & 4.4 & 0.0 & 5.4 \\
\hline & $N$ & 475 & 90 & 385 & 278 & 197 & 159 & 316 & 139 & 336 \\
\hline \multirow{7}{*}{$\begin{array}{l}\text { 22. Do you think that a dividend decrease } \\
\text { tells you something about the company's } \\
\text { future performance? A dividend decrease } \\
\text { is an indication that the future performance: } \\
\text { ( } 1 \text { = will deteriorate strongly; } 7 \text { = will } \\
\text { improve strongly) }\end{array}$} & Mean & $3.56^{\bullet \bullet}$ & 3.52 & 3.57 & 3.54 & 3.59 & 3.51 & 3.59 & 3.51 & 3.58 \\
\hline & $t$-stat & -11.77 & -4.90 & -10.74 & -9.15 & -7.39 & -7.80 & -8.94 & -7.55 & -9.22 \\
\hline & Median & 4 & 4 & 4 & 4 & 4 & 4 & 4 & 4 & 4 \\
\hline & Binomial $p$ & 0.0000 & 0.0000 & 0.0000 & 0.0000 & 0.0000 & 0.0000 & 0.0000 & 0.0000 & 0.0000 \\
\hline & $\%(>4)$ & 5.9 & 5.6 & 5.9 & 4.7 & 7.5 & 3.8 & 6.9 & 4.3 & 6.5 \\
\hline & $\%(<4)$ & 41.6 & 41.6 & 41.6 & 41.0 & 42.5 & 46.2 & 39.4 & 47.1 & 39.4 \\
\hline & $N$ & 478 & 89 & 389 & 278 & 200 & 158 & 320 & 138 & 340 \\
\hline \multicolumn{11}{|c|}{ Theory i. The choice between cash dividends and share buy-backs } \\
\hline \multirow{7}{*}{$\begin{array}{l}\text { 23. Suppose a company would stop paying } \\
\text { dividends and instead use the money to buy } \\
\text { back its own stocks on the market. How } \\
\text { would you value such a decision? ( } 1= \\
\text { extremely negative; } 4=\text { neutral; } 7= \\
\text { extremely positive) }\end{array}$} & Mean & $3.81^{\bullet+\bullet}$ & 3.76 & 3.82 & 3.86 & 3.74 & $4.10 * * *$ & $3.66 * * *$ & 3.92 & 3.77 \\
\hline & $t$-stat & -2.67 & -1.47 & -2.25 & -1.55 & -2.28 & 0.82 & -3.92 & -0.63 & -2.69 \\
\hline & Median & 4 & 4 & 4 & 4 & 4 & $4^{* *}$ & $4^{* *}$ & 4 & 4 \\
\hline & Binomial $p$ & 0.4821 & 1.0000 & 0.4340 & 0.6154 & 0.6812 & 0.2352 & 0.0697 & 0.5900 & 0.2350 \\
\hline & $\%(>4)$ & 34.7 & 35.9 & 34.5 & 33.7 & 36.2 & 42.1 & 31.0 & 35.9 & 34.3 \\
\hline & $\%(<4)$ & 37.7 & 35.9 & 38.2 & 36.6 & 39.3 & 33.3 & 39.9 & 31.3 & 40.1 \\
\hline & $N$ & 472 & 92 & 380 & 276 & 196 & 159 & 313 & 128 & 344 \\
\hline \multirow{7}{*}{$\begin{array}{l}\text { 24. Do you think that a stock repurchase is } \\
\text { good because it is a signal that the stock is } \\
\text { undervalued? ( } 1 \text { = no, definitely not; } 4= \\
\text { neutral; } 7 \text { = yes, definitely) }\end{array}$} & Mean & $4.36 \bullet$ & 4.44 & 4.34 & 4.40 & 4.30 & $4.52^{* *}$ & $4.28 * *$ & 4.35 & 4.36 \\
\hline & t-stat & 5.85 & 3.15 & 4.96 & 5.01 & 3.15 & 5.35 & 3.51 & 2.94 & 5.07 \\
\hline & Median & 4 & 4 & 4 & 4 & 4 & 5 & 4 & 4 & 4 \\
\hline & Binomial $p$ & 0.0000 & 0.0006 & 0.0000 & 0.0000 & 0.0001 & 0.0000 & 0.0000 & 0.0006 & 0.0000 \\
\hline & $\%(>4)$ & 45.6 & 48.3 & 44.9 & 47.1 & 43.5 & 50.3 & 43.1 & 45.7 & 45.6 \\
\hline & $\%(<4)$ & 18.5 & 18.0 & 18.6 & 17.5 & 19.9 & 15.7 & 20.0 & 20.5 & 17.7 \\
\hline & $N$ & 443 & 89 & 354 & 257 & 186 & 153 & 290 & 127 & 316 \\
\hline
\end{tabular}




\begin{tabular}{|c|c|c|c|c|c|c|c|c|c|c|}
\hline Abbreviated question description & Statistics & $\begin{array}{c}\text { All } \\
\text { investors }\end{array}$ & $\begin{array}{l}\text { Owning } \\
\text { stocks } \\
\text { only }\end{array}$ & $\begin{array}{l}\text { Owning } \\
\text { funds (and } \\
\text { perhaps } \\
\text { stocks) }\end{array}$ & $\begin{array}{c}\text { Age below } \\
55\end{array}$ & $\begin{array}{l}\text { Age above } \\
55\end{array}$ & $\begin{array}{c}\text { High } \\
\text { income }\end{array}$ & $\begin{array}{c}\text { Low } \\
\text { income }\end{array}$ & $\begin{array}{l}\text { University } \\
\text { educated }\end{array}$ & $\begin{array}{c}\text { No } \\
\text { university } \\
\text { education }\end{array}$ \\
\hline \multicolumn{11}{|c|}{ Theoryj. Taxes } \\
\hline \multirow{7}{*}{$\begin{array}{l}\text { 25. Please indicate on the following scale } \\
\text { whether you like your stocks to pay } \\
\text { dividends or not for tax reasons under the } \\
\text { new tax regime. ( } 1=\text { no, definitely not; } 7= \\
\text { yes, definitely) }\end{array}$} & Mean & $3.60 \bullet$ & 3.61 & 3.60 & 3.60 & 3.60 & 3.57 & 3.61 & 3.62 & 3.59 \\
\hline & t-stat & -5.72 & -2.78 & -5.04 & -4.63 & -3.45 & -3.46 & -4.55 & -3.04 & -4.84 \\
\hline & Median & $4^{\bullet \bullet}$ & 4 & 4 & 4 & 4 & 4 & 4 & 4 & 4 \\
\hline & Binomial $p$ & 0.0001 & 0.0079 & 0.0015 & 0.0024 & 0.0093 & 0.0034 & 0.0052 & 0.0049 & 0.0032 \\
\hline & $\%(>4)$ & 19.0 & 13.5 & 20.3 & 17.2 & 21.5 & 18.2 & 19.4 & 15.9 & 20.3 \\
\hline & $\%(<4)$ & 32.6 & 33.7 & 32.3 & 30.2 & 35.6 & 35.8 & 30.9 & 33.3 & 32.2 \\
\hline & $N$ & 473 & 89 & 384 & 268 & 205 & 159 & 314 & 138 & 335 \\
\hline \multirow{7}{*}{$\begin{array}{l}\text { 26. Please indicate on the following scale } \\
\text { whether you used to like stocks to pay } \\
\text { dividends or not for tax reasons under the } \\
\text { old income tax regime (prevailing before } \\
\text { January } 1,2001) \text {. ( } 1 \text { = no, definitely not; } 7 \\
=\text { yes, definitely) }\end{array}$} & Mean & $3.79^{\bullet \bullet \bullet}$ & 3.72 & 3.80 & $3.94^{* *}$ & $3.59 * *$ & $3.58 * *$ & $3.89 * *$ & 3.68 & 3.84 \\
\hline & $t$-stat & -2.96 & -1.95 & -2.39 & -0.70 & -3.50 & -3.40 & -1.22 & -2.57 & -1.90 \\
\hline & Median & 4 & 4 & 4 & $4^{* *}$ & $4 * *$ & $4 * *$ & $4^{* *}$ & 4 & 4 \\
\hline & Binomial $p$ & 0.0746 & 0.1641 & 0.2086 & 1.0000 & 0.0078 & 0.0124 & 0.8091 & 0.0344 & 0.4952 \\
\hline & $\%(>4)$ & 24.0 & 18.4 & 25.3 & 24.5 & 23.2 & 22.2 & 24.8 & 20.3 & 25.5 \\
\hline & $\%(<4)$ & 30.3 & 29.9 & 30.4 & 24.1 & 38.7 & 38.6 & 26.2 & 34.6 & 28.6 \\
\hline & $N$ & 455 & 87 & 368 & 261 & 194 & 153 & 302 & 133 & 322 \\
\hline \multirow{5}{*}{$\begin{array}{l}\text { 27. Did you submit an income tax form for } \\
\text { the year } 2001 \text { in order to ask for a } \\
\text { reimbursement of the dividend surtax } \\
\text { ("dividendbelasting")? ( } 1=\text { yes; } 0=\text { no) }\end{array}$} & Mean & $0.40 \bullet$ & $0.19 * * *$ & $0.44^{* * *}$ & $0.35^{* * *}$ & $0.47 * * *$ & $0.46^{* *}$ & $0.37^{* *}$ & 0.44 & 0.38 \\
\hline & $t$-stat ${ }^{\text {a, b }}$ & -4.99 & -7.81 & -2.46 & -5.80 & -0.94 & -0.98 & -5.42 & -1.39 & -5.02 \\
\hline & Median & $0 \bullet$ & $0 * * *$ & $0 * * *$ & $0 * * *$ & $0 * * *$ & $0 * *$ & $0 * *$ & 0 & 0 \\
\hline & Binomial $p^{\text {a }}$ & 0.0000 & 0.0000 & 0.0164 & 0.0000 & 0.3830 & 0.3644 & 0.0000 & 0.1927 & 0.0000 \\
\hline & $N$ & 555 & 103 & 452 & 333 & 222 & 175 & 380 & 151 & 404 \\
\hline
\end{tabular}

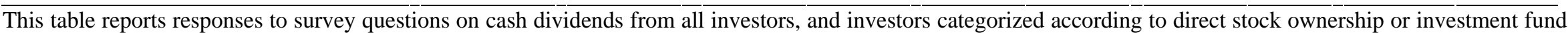

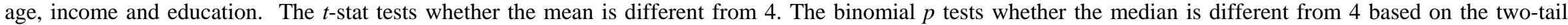

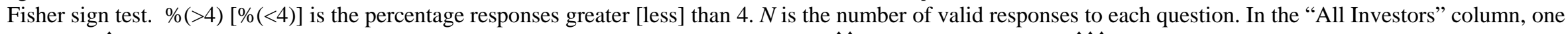

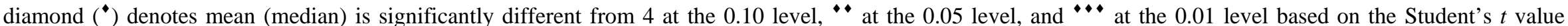

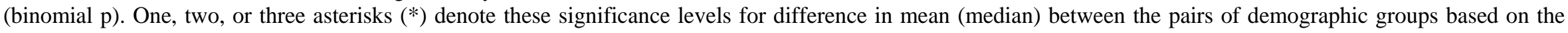
two-sample $t$-test (non-parametric median test).

${ }^{a}$ The $t$-stat (binomial p) for Question 27 is for testing whether the mean (median) response is different from 0.5 .

${ }^{\mathrm{b}}$ Statistical significance of the difference in means between subgroups for Question 27 is based on the Z-test for the difference in two proportions. 
Table 3

Responses to General Dividend Questions

\begin{tabular}{|c|c|c|c|c|c|c|c|c|}
\hline Abbreviated question description & Statistics & $\begin{array}{c}\text { All } \\
\text { investors }\end{array}$ & $\begin{array}{c}\text { Age below } \\
55 \\
\end{array}$ & $\begin{array}{c}\text { Age above } \\
55 \\
\end{array}$ & $\begin{array}{c}\text { High } \\
\text { income }\end{array}$ & $\begin{array}{c}\text { Low } \\
\text { income }\end{array}$ & $\begin{array}{c}\text { University } \\
\text { educated }\end{array}$ & $\begin{array}{c}\text { No } \\
\text { university } \\
\text { education }\end{array}$ \\
\hline \multirow{7}{*}{$\begin{array}{l}\text { 5. Do you hold some shares in investment } \\
\text { funds in addition to holding shares in } \\
\text { individual companies directly, because } \\
\text { investment funds pay more reliable } \\
\text { dividends? ( } 1=\text { completely disagree; } 4= \\
\text { neutral; } 7 \text { = completely agree) }\end{array}$} & Mean & $3.68^{\bullet+}$ & 3.54 & 3.86 & $3.45^{*}$ & 3.83* & 3.49 & 3.77 \\
\hline & $t$-stat & -3.03 & -3.26 & -0.90 & -3.08 & -1.32 & -2.69 & -1.85 \\
\hline & Median & 4 & 4 & 4 & $4^{*}$ & $4^{*}$ & 4 & 4 \\
\hline & Binomial $p$ & 0.2315 & 0.1766 & 0.8957 & 0.0674 & 1.0000 & 0.1839 & 0.6752 \\
\hline & $\%(>4)$ & 27.1 & 26.8 & 27.5 & 25.3 & 28.3 & 26.1 & 27.6 \\
\hline & $\%(<4)$ & 33.8 & 37.4 & 29.4 & 42.5 & 28.3 & 40.6 & 30.8 \\
\hline & $N$ & 225 & 123 & 102 & 87 & 138 & 69 & 156 \\
\hline \multirow{7}{*}{$\begin{array}{l}\text { 6. Do you hold shares in investment funds } \\
\text { only and no shares in individual } \\
\text { companies, because investment funds pay } \\
\text { more reliable dividends? ( } 1=\text { completely } \\
\text { disagree; } 4=\text { neutral; } 7=\text { completely agree })\end{array}$} & Mean & 4.00 & $3.74^{* * *}$ & $4.39 * * *$ & 3.71 & 4.11 & $3.53^{* *}$ & $4.16^{* *}$ \\
\hline & $t$-stat & 0.00 & -1.86 & 1.97 & -1.16 & 0.86 & -1.85 & 1.26 \\
\hline & Median & 4 & $4 * * *$ & $4 * * *$ & 4 & 4 & 4 & 4 \\
\hline & Binomial $p$ & 0.2313 & 0.7035 & 0.0222 & 0.6177 & 0.0598 & 0.5966 & 0.0662 \\
\hline & $\%(>4)$ & 33.5 & 24.6 & 46.8 & 29.1 & 35.2 & 27.5 & 35.6 \\
\hline & $\%(<4)$ & 26.4 & 28.0 & 24.1 & 36.4 & 22.5 & 35.3 & 23.3 \\
\hline & $N$ & 197 & 118 & 79 & 55 & 142 & 51 & 146 \\
\hline
\end{tabular}

This table reports responses to general dividends questions from all investors, and investors categorized according to direct stock ownership or investment fund, age, income and education. The $t$-stat tests whether the mean is different from 4 . The binomial $p$ tests whether the median is different from 4 based on the two-tail Fisher sign test. $\%(>4)[\%(<4)]$ is the percentage responses greater [less] than $4 . N$ is the number of valid responses to each question. In the "All Investors" column, one diamond ( ) denotes mean (median) response is significantly different from 4 at the 0.10 level, ${ }^{\bullet}$ at the 0.05 level, and ${ }^{\bullet \bullet}$ at the 0.01 level based on the Student's $t$ value (binomial $p$ ). One, two, or three asterisks $\left(^{*}\right)$ denote these significance levels for difference in mean (median) between the pairs of demographic groups based on the two-sample $t$-test (non-parametric median test). 
Table 4

Responses to Behavioral Finance Questions

\begin{tabular}{|c|c|c|c|c|c|c|c|c|c|c|}
\hline Abbreviated question description & Statistics & $\begin{array}{c}\text { All } \\
\text { investors }\end{array}$ & $\begin{array}{c}\text { Owning } \\
\text { stocks } \\
\text { only }\end{array}$ & $\begin{array}{l}\text { Owning } \\
\text { funds (and } \\
\text { perhaps } \\
\text { stocks) }\end{array}$ & $\begin{array}{c}\text { Age belov } \\
55\end{array}$ & $\begin{array}{l}\text { Age above } \\
55\end{array}$ & $\begin{array}{l}\text { High } \\
\text { income }\end{array}$ & $\begin{array}{l}\text { Low } \\
\text { income }\end{array}$ & $\begin{array}{l}\text { University } \\
\text { educated }\end{array}$ & $\begin{array}{c}\text { No } \\
\text { university } \\
\text { education }\end{array}$ \\
\hline \multirow{3}{*}{$\begin{array}{l}14 \text {. How much of the total dividends that you } \\
\text { receive do you use for current consumption } \\
\text { purposes? ( } 1=0-20 \% \text { of the total amount; } 2=20- \\
40 \% \text { of the total amount; } 3=40-60 \% \text { of the total } \\
\text { amount; } 4=60-80 \% \text { of the total amount; } 5=80- \\
100 \% \text { of the total amount) }\end{array}$} & Mean & 1.83 & 1.89 & 1.81 & $1.69 * *$ & $2.00^{* *}$ & $1.54^{* * *}$ & $1.96^{* * *}$ & 1.75 & 1.86 \\
\hline & Median & 1 & 1 & 1 & $1 * *$ & $1 * *$ & $1 * *$ & $1^{* *}$ & 1 & 1 \\
\hline & $N$ & 379 & 64 & 315 & 210 & 169 & 123 & 256 & 102 & 277 \\
\hline \multirow{3}{*}{$\begin{array}{l}\text { 15. How much of the total income that you } \\
\text { receive from regular salary (including } \\
\text { pension) and social benefits do you use for } \\
\text { consumption purposes? ( } 1=0-20 \% \text { of the total } \\
\text { amount; } 2=20-40 \% \text { of the total amount; } 3=40-40-80 \% \text { of the total } \\
60 \% \text { of the total amount; } 4=60-80 \% \text { of the tolal amount) } \\
\text { amount; } 5=80-100 \% \text { of the }\end{array}$} & Mean & 3.13 & 3.19 & 3.12 & $2.95 * * *$ & $3.37 * * *$ & 3.19 & 3.10 & 3.20 & 3.10 \\
\hline & Median & 3 & 3 & 3 & $3^{* * *}$ & $4 * * *$ & 3 & 3 & 3 & 3 \\
\hline & $N$ & 492 & 90 & 402 & 282 & 210 & 161 & 331 & 135 & 357 \\
\hline \multirow[t]{7}{*}{ Difference $14-15$} & Mean & $-1.44^{\bullet \bullet}$ & -1.35 & -1.46 & -1.44 & -1.44 & $-1.72 * *$ & $-1.30 * *$ & $-1.68 *$ & $-1.35^{*}$ \\
\hline & $t$-stat ${ }^{\mathrm{a}}$ & -16.33 & -6.06 & -15.17 & -11.80 & -11.30 & -12.54 & -11.65 & -10.00 & -13.10 \\
\hline & Median & $-2^{\bullet+}$ & -1 & -2 & -2 & -2 & -2 & -1 & -2 & -1 \\
\hline & Binomial $p^{\text {a }}$ & 0.0000 & 0.0000 & 0.0000 & 0.0000 & 0.0000 & 0.0000 & 0.0000 & 0.0000 & 0.0000 \\
\hline & $\%(>0)$ & 12.7 & 16.7 & 11.9 & 13.1 & 12.3 & 8.5 & 14.8 & 11.3 & 13.2 \\
\hline & $\%(<0)$ & 71.5 & 70.0 & 71.9 & 72.9 & 69.9 & 81.4 & 66.8 & 77.3 & 69.4 \\
\hline & $N$ & 362 & 60 & 302 & 199 & 163 & 118 & 244 & 97 & 265 \\
\hline \multirow{7}{*}{$\begin{array}{l}\text { 16. Would you for consumption purposes sell } \\
\text { part of your stocks in a company that has } \\
\text { always paid a dividend, if the management of } \\
\text { that company would decide not to pay a } \\
\text { dividend anymore? ( } 1=\text { no, definitely not; } 4 \\
=\text { neutral; } 7 \text { = yes, definitely) }\end{array}$} & Mean & $2.87^{\bullet+\bullet}$ & 2.89 & 2.86 & $2.68^{* * *}$ & $3.13^{* * *}$ & $2.57^{* * *}$ & $3.02^{* * *}$ & 2.75 & 2.91 \\
\hline & $t$-stat & -14.08 & -5.83 & -12.82 & -12.82 & -6.92 & -10.93 & -9.77 & -8.18 & -11.48 \\
\hline & Median & $2 \cdots$ & 2 & 2 & $2 * * *$ & $3^{* * *}$ & $2 * * *$ & $3^{* * *}$ & 2 & 2 \\
\hline & Binomial $p$ & 0.0000 & 0.0000 & 0.0000 & 0.0000 & 0.0000 & 0.0000 & 0.0000 & 0.0000 & 0.0000 \\
\hline & $\%(>4)$ & 15.9 & 14.1 & 16.3 & 12.8 & 20.1 & 11.4 & 18.2 & 16.5 & 15.6 \\
\hline & $\%(<4)$ & 60.6 & 59.8 & 60.8 & 63.7 & 56.3 & 68.4 & 56.7 & 63.2 & 59.6 \\
\hline & $N$ & 472 & 92 & 380 & 273 & 199 & 158 & 314 & 133 & 339 \\
\hline
\end{tabular}

This table reports responses to behavioral finance questions (Theory e) from all investors as well as demographic groups. $N$ is the number of valid responses to each question. One diamond ( $\left(^{\star}\right)$ denotes mean (median) response is significantly different from 4 (or 0, for Difference14-15) at the 0.10 level, ${ }^{\bullet \bullet}$ at the 0.05 level, and ${ }^{\bullet \bullet}$ at the 0.01 level based on the Student's $t$ value (binomial $p$ ). One, two, or three asterisks $(*)$ denote those significance levels for difference in mean (median) between the pairs of demographic groups based on the two-sample $t$-test (non-parametric median test).

${ }^{a}$ The $t$-stat (binomial $p$ ) for "Difference 14-15" is for testing whether the mean (median) difference in responses to Question 14 and Question 15 is different from 0. 
Table 5

Responses to Questions on Stock Dividends

\begin{tabular}{|c|c|c|c|c|c|c|c|c|c|c|}
\hline Abbreviated question description & Statistics & $\begin{array}{c}\text { All } \\
\text { investors }\end{array}$ & $\begin{array}{c}\text { Owning } \\
\text { stocks } \\
\text { only }\end{array}$ & $\begin{array}{l}\text { Owning } \\
\text { funds (and } \\
\text { perhaps } \\
\text { stocks) }\end{array}$ & $\begin{array}{c}\text { Age belor } \\
55\end{array}$ & $\begin{array}{c}\text { Age above } \\
55\end{array}$ & $\begin{array}{l}\text { High } \\
\text { income }\end{array}$ & $\begin{array}{l}\text { Low } \\
\text { income }\end{array}$ & $\begin{array}{l}\text { University } \\
\text { educated }\end{array}$ & $\begin{array}{c}\text { No } \\
\text { university } \\
\text { education }\end{array}$ \\
\hline \multicolumn{11}{|c|}{ Theory k. Stock dividends as small stock splits } \\
\hline \multirow{4}{*}{$\begin{array}{l}\text { 28. Stock dividends are: }(1=\text { more like } \\
\text { cash dividends; } 7=\text { more like stock splits })\end{array}$} & $t$-stat & 2.04 & 1.63 & 1.50 & 1.76 & 1.08 & 0.05 & 2.60 & 0.59 & 2.09 \\
\hline & Median & $4^{*+\cdot}$ & 4 & 4 & 4 & 4 & 4 & 4 & 4 & 4 \\
\hline & Binomial $p$ & 0.0036 & 0.0541 & 0.0238 & 0.0128 & 0.1388 & 0.6208 & 0.0013 & 0.3374 & 0.0051 \\
\hline & $N$ & 405 & 76 & 329 & 230 & 175 & 140 & 265 & 122 & 283 \\
\hline \multicolumn{11}{|c|}{ Theory l. Transaction costs } \\
\hline \multirow{4}{*}{$\begin{array}{l}\text { 29. Can you please give your opinion on a } \\
\text { scale from } 1 \text { to } 7 \text { on the following } \\
\text { statement? Because of transaction costs I } \\
\text { have a preference for stock dividends over } \\
\text { cash dividends. ( } 1 \text { = No, definitely not; } 7= \\
\text { Yes, definitely) }\end{array}$} & Mean & $4.40^{* \cdot \bullet}$ & 4.17 & 4.46 & 4.38 & 4.43 & 4.27 & 4.47 & 4.46 & 4.38 \\
\hline & $t$-stat & 5.47 & 0.86 & 5.80 & 4.06 & 3.66 & 1.95 & 5.41 & 3.38 & 4.33 \\
\hline & Median & $4^{\bullet+}$ & $4^{*}$ & $4^{*}$ & 4 & 4 & 4 & 4 & 4 & 4 \\
\hline & Binomial $p$ & 0.0000 & 0.4614 & 0.0000 & 0.0000 & 0.0000 & 0.0127 & 0.0000 & 0.0001 & 0.0000 \\
\hline you currently have a preference for stock or & $t$-stat & 1.47 & 2.59 & 0.48 & 2.57 & -0.47 & 0.06 & 1.78 & 2.17 & 0.46 \\
\hline for cash dividends? Please answer this & Median & $4^{* *}$ & $4^{*}$ & $4^{*}$ & $4 * *$ & $4^{* *}$ & 4 & 4 & & 4 \\
\hline question in the context of the currently & Binomial $p$ & 0.0231 & 0.0090 & 0.2128 & 0.0012 & 1.0000 & 0.6201 & 0.0193 & 0.0534 & 0.1592 \\
\hline $\begin{array}{l}\text { prevaling tax system that is operanonal } \\
\text { since January } 2001(1=\mathrm{I} \text { prefer cash }\end{array}$ & $\%(>4)$ & 28.8 & 34.7 & 27.5 & 31.0 & 26.0 & 25.2 & 30.7 & 29.1 & 28.7 \\
\hline dividends; 7 = I prefer stock dividends) & $\%(<4)$ & 20.6 & 12.5 & 22.4 & 15.9 & 26.6 & 21.6 & 20.1 & 16.2 & 22.4 \\
\hline & $N$ & 403 & 72 & 331 & 226 & 177 & 139 & 264 & 117 & 286 \\
\hline
\end{tabular}




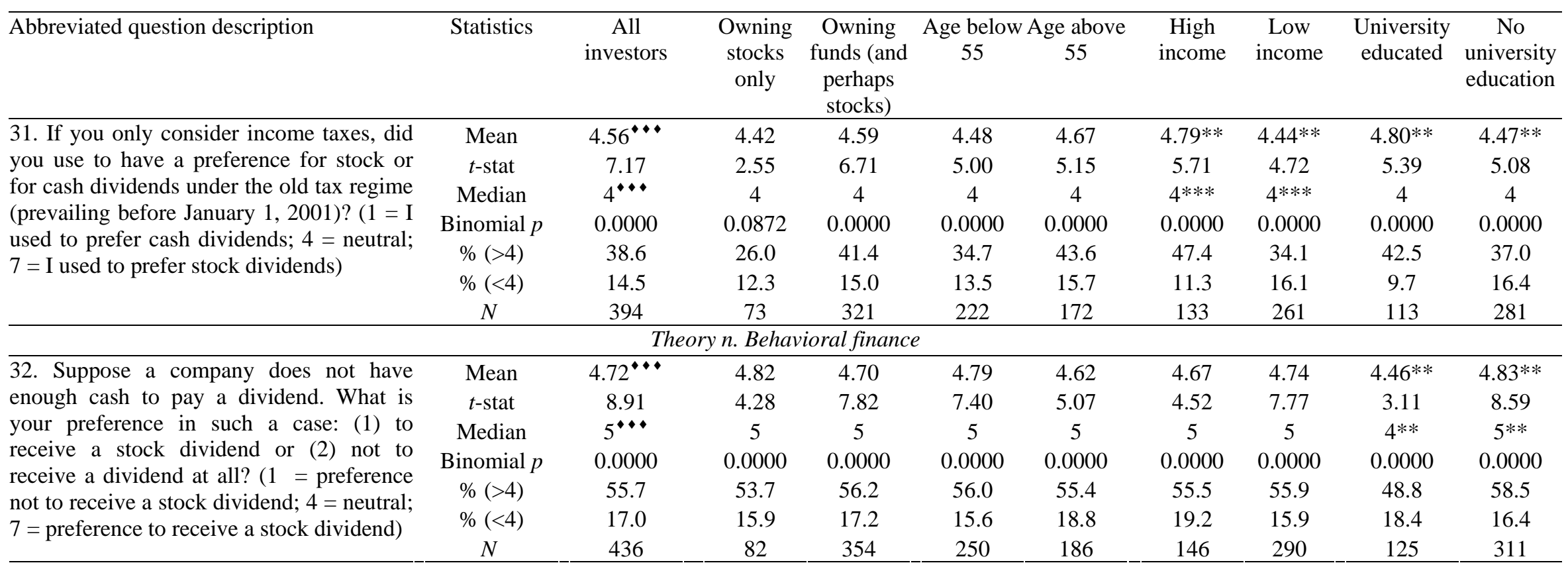

This table reports responses to survey questions on cash dividends from all investors, and investors categorized according to direct stock ownership or investment fund age, income and education. The $t$-stat tests whether the mean is different from 4 . The binomial $p$ tests whether the median is different from 4 based on the two-tail Fisher sign test. $\%(>4)[\%(<4)]$ is the percentage responses greater [less] than $4 . N$ is the number of valid responses to each question. In the "All Investors" column, one diamond ( $\left.{ }^{\star}\right)$ denotes mean (median) response is significantly different from 4 at the 0.10 level, ${ }^{\bullet \bullet}$ at the 0.05 level, and ${ }^{\bullet \bullet}$ at the 0.01 level based on the Student's $t$ value (binomial $p$ ). One, two, or three asterisks $\left(^{*}\right.$ ) denote these significance levels for difference in mean (median) between the pairs of demographic groups based on the two-sample $t$-test (non-parametric median test). 
Appendix table

Summary of theories and results

\begin{tabular}{ll}
\hline Theories supported & \multicolumn{1}{c}{ Results } \\
\hline b. Transaction costs & Dividends save transaction costs \\
\hline h. Signaling & $\begin{array}{l}\text { Dividend increase (decrease) signals strong (poor) future } \\
\text { performance }\end{array}$ \\
\hline i. Stock repurchase & Repurchases signal stock undervaluation \\
\hline l. Transaction costs (stock dividends) & $\begin{array}{l}\text { Investors prefer stock dividends to cash dividends } \\
\text { because of transaction costs, implying that investors tend } \\
\text { to reinvest cash dividends }\end{array}$ \\
\hline$n$. Behavioral finance (stock dividends) & $\begin{array}{l}\text { Investors prefer stock dividends even though stock } \\
\text { dividends are no more than stock splits }\end{array}$ \\
\hline
\end{tabular}

\begin{tabular}{ll}
\hline Theories not supported & \multicolumn{1}{c}{ Results } \\
\hline c. Uncertainty resolution & $\begin{array}{l}\text { Investors do not view dividend-paying stocks as less } \\
\text { risky }\end{array}$ \\
\hline d. Accounting manipulations & $\begin{array}{l}\text { Investors (especially young investors) do not believe } \\
\text { dividends offer assurance of earnings quality }\end{array}$ \\
\hline e. Behavioral theory & $\begin{array}{l}\text { Investors consume less from dividends than from regular } \\
\text { income }\end{array}$ \\
\hline$f$. Free cash flow & $\begin{array}{l}\text { Investors do not believe dividends control for free cash } \\
\text { flow problems }\end{array}$ \\
\hline$g$. Agency costs & $\begin{array}{l}\text { Investors do not believe that dividends force companies } \\
\text { to be monitored by capital markets and therefore reduce } \\
\text { agency costs }\end{array}$ \\
\hline$j$. Taxes & $\begin{array}{l}\text { Taxes do not seem to play a primary role in investors’ } \\
\text { decision on dividends }\end{array}$ \\
\hline
\end{tabular}

Note: Theories and results apply to cash dividends unless "stock dividends" is specified. The theories are numbered according to Sections 2 and 3. 